\title{
渤海湾盆地东部古近系层序地层及其对构造 活动的响应
}

冯有良 ${ }^{(1)}$, 周海民 ${ }^{(1)}$, 任建业 ${ }^{(2)}$, 郑和荣 ${ }^{3}$, 苗顺德 ${ }^{(1)}$

\author{
(1) 中国石油勘探开发研究院, 北京 100083; \\ (2) 中国地质大学资源学院, 武汉 430074; \\ (3) 中石化勘探开发研究院, 北京 100083 \\ *E-mail: fyouliang @ petrochina.com.cn
}

收稿日期: 2009-09-07; 接受日期: 2010-05-12

科技部十五科技攻关项目(编号: 2003BA613A-01)和国家自然科学基金(批准号: 40072039)资助

\begin{abstract}
摘要充分应用渤海湾盆地东部研究程度相对较高的济阳、黄骅及辽河坳陷丰富的钻 井、岩芯和三维地震资料, 以构造层序分析的方法对渤海湾盆地东部古近系同裂谷期地 层进行了层序地层研究. 据渤海湾盆地东部古近系同裂谷期构造演化、地层组合及不整 合面发育特征, 将古近系划分为一个超层序组 (一级层序), 四个与裂陷幕对应的超层序 (二级层序), 10 12 个三级层序. 超层序 1 、超层序 2 分别相当于孔店组 $\left(\mathrm{E}_{1-2} k_{1}\right)$ 和沙四段 $\left(\mathrm{E}_{2} s_{4}\right)$, 发育在裂陷一、二幕盆地基地沉降速率小、断陷伸展作用较弱的构造背景和较为 干旱的气候条件下, 发育同沉积断裂坡折(背景)层序. 超层序 3 相当于沙三段 $\left(\mathrm{E}_{2} s_{3}\right.$ ) 和沙 二段 $\left(\mathrm{E}_{2} s_{2}\right)$, 形成于裂陷三幕盆地基底沉降速率和伸展速率最大, 盆地断陷、伸展作用强 烈的构造背景和温暖湿润的气候条件下, 主要发育同沉积断裂坡折和挠曲坡折(背景)层 序. 超层序 4 相当于沙一 $\left(\mathrm{E}_{3} s_{1}\right)$ 和东营组 $\left(\mathrm{E}_{3} d\right)$, 形成于裂陷四幕渤海湾陆上盆地基底沉降 速率和伸展速率减小, 滩海及海域盆地基底沉降速率和伸展速率有所增强的构造背景 下, 在盆地基底沉降中心区(滩海及海域)发育与超层序 3 相似的同沉积构造坡折(背景) 层序。而在陆上区域主要发育挠曲坡折和缓坡(背景)层序。超层序 2 和 3 内发育的三级层 序低位域砂体的发育主要受同沉积断裂坡折带的控制，并沿同沉积断裂坡折带分布。凹 陷内同沉积断裂坡折带从早期层序到晚期层序由凹陷边缘向中心迁移，因此同沉积断裂 坡折带及受其控制的低位域砂体的发育带也由凹陷边缘向中心迁移. 由于层序低位域砂 体发育带分布在湖扩展域泥岩之下, 其成藏条件良好, 是岩性油气藏勘探的有利区带.
\end{abstract}

\section{关键词}

断陷盆地 幕式裂陷 层序地层 同沉积构造坡折带 层序地层形式 岩性油气藏 渤海湾盆地 古近系
渤海湾盆地作为中国东部含油气最为丰富的中、 新生代裂谷盆地, 已进行了 40 多年的石油勘探开发, 积累了大量的岩芯、地层古生物、测井和高精度三维
地震资料，为在该盆地进行层序地层研究奠定了基 础. 自 20 世纪 80 年代末以来, 源于被动大陆边缘的 经典层序地层学引入我国, 我国学者在渤海湾盆地

引用格式: Feng Y L, Zhou H M, Ren J Y, et al. Paleogene sequence stratigraphy in the east of the Bohai Bay Basin and its response to structural movement (in Chinese). Sci Sin Terrae, 2010, 40: 1356-1376 
就率先进行了大量的层序地层学研究 ${ }^{[1 \sim 4]}$. 逐步建立 了适合渤海湾断陷盆地特征的层序级别划分、层序界 面识别标志、层序体系域构成模式, 提出了与 I 型层 序陆架坡折相当的同沉积构造坡折带的概念 ${ }^{[3 \sim 5]}$, 并 把这一概念成功的应用于层序体系域构成模式的建 立、储层预测和砂岩隐蔽油气藏的勘探 ${ }^{[6]}$. 渤海湾盆 地作为一个构造活跃的裂谷型断陷盆地, 其层序地 层的发育与盆地幕式构造运动、区域构造背景关系极 为密切. 盆地层序充填及其特征的研究, 对于理解渤 海湾盆地区域构造活动以及构造活动对层序地层形 成的控制作用有十分重要的意义. 本文旨在通过对 渤海湾盆地东部济阳坳陷、黄骅坳陷及下辽河坳陷古 近系层序地层研究, 探讨渤海湾盆地古近系层序地 层的发育特征及其对盆地及区域构造活动的沉积响 应.

\section{1 地质背景}

渤海湾盆地是中国东部含油气极为丰富的中新 生代裂谷盆地, 面积约 $15 \times 10^{5} \mathrm{~km}^{2}$. 其西缘、东缘、 北缘和南缘分别以太行山东侧断裂、郯庐断裂、燕山 南缘断裂、齐河-广饶及兰考-聊城断裂为界, 分别与 太行山隆起、胶辽隆起、燕山褶皱带及鲁西隆起毗邻. 走向 NE, NEE, NW 的主要控盆断裂把盆地分割为一 系列走向呈 NE, NEE-EW 的坳陷和隆起. 其中最为 主要的坳陷有位于盆地西部的呈 NE 走向的冀中坳陷, 位于盆地东南部的呈 NE-NEE 走向的黄骅坳陷、济阳 坳陷, 位于盆地东部渤海海域的呈 NE, NW 走向的渤 中坳陷, 以及位于盆地东北部的呈 NE 走向的辽河坳 陷. 沧县隆起以西的冀中坳陷, 发育 $\mathrm{NE}$ 走向的伸展 构造, 坳陷北段为西断东超、南段为东断西超的复式 半地堑结构. 沧县隆起以东的济阳坳陷、黄骅坳陷构 造线在平面上为向 $\mathrm{NE}$ 方向撒开的“帚状”, 发育 NE-NEE 走向的张扭构造. 坳陷总体表现为西断东 超、北断南超的大型宽缓半地堑结构. 位于郯庐断裂 构造带中的辽河坳陷发育 NE 走向的伸展构造, 坳陷 总体表现为东断西超和西断东超的背向排列的半地 堑结构. 位于渤海海域的渤中坳陷, 发育 $\mathrm{NE}$ 和 $\mathrm{NW}$ 向构造, 㘬陷总体表现为东断西超和北断南超的半 地堑结构(图 1). 渤海湾新生代裂谷盆地是在晚侏罗 世-早白严世中生代裂谷盆地的基础上发展而来. 古 近纪裂陷期地层自下而上分别发育了孔店组 $\left(\mathrm{E}_{1-2} k\right)$ 、
沙河街组 $\left(\mathrm{E}_{2} s\right)$ 和东营组 $\left(\mathrm{E}_{3} d\right)$. 孔店组 $\left(\mathrm{E}_{1-2} k\right)$ 底部发育 砾岩、含砾砂岩、粗砂岩夹紫红色泥岩, 中部为灰色 泥岩、油页岩与中细砂岩互层, 上部为红色砂岩和泥 岩互层, 是一套冲积扇、扇三角洲、半深湖、滨浅湖 到河流相沉积. 沙河街组四段 $\left(\mathrm{E}_{2} s_{4}\right)$ 底部发育红色砂 岩与红色泥岩互层夹盐膏层, 上部发育灰色泥岩、油 页岩夹砂岩及薄层灰岩, 是一套盐湖到微咸水湖泊 相沉积. 沙河街组三段 $\left(\mathrm{E}_{2} S_{3}\right)$ 底部发育灰色、深灰色泥 岩、油页岩, 是一套深湖及浊流相沉积; 中上部发育 细砂岩夹灰色泥岩及粗砂岩、含砾砂岩夹灰绿色泥岩, 是一套河流-三角洲相沉积. 沙河街组二段 $\left(\mathrm{E}_{2} \mathrm{~S}_{2}\right)$ 发育 砾岩、含砾砂岩及砂岩夹紫红色泥岩, 是一套河流相 沉积; 沙一段 $\left(\mathrm{E}_{3} \mathrm{~s}_{1}\right)$ 底部发育砾岩、粗砂岩夹红色泥岩, 是一套辫状河沉积; 中部发育灰色泥岩油页岩夹薄 层灰岩是一套湖泊相沉积; 上部发育砂岩夹灰色泥 岩是一套三角洲相沉积. 东营组 $\left(\mathrm{E}_{3} d\right)$ 发育粗砂岩、含 砾砂岩、细砾岩夹灰色泥岩、灰绿色及紫红色泥岩是 一套冲积扇、辫状三角洲相为主的沉积. 新近纪后裂 谷期盆地发育了馆陶组 $\left(\mathrm{N}_{1} g\right)$ 、明化镇组 $\left(\mathrm{N}_{2} m\right)$. 馆陶 组 $\left(\mathrm{N}_{1} g\right)$ 发育中细砾岩、粗砂岩夹灰绿色、紫红色泥 岩为一套辫状河到曲流河相沉积; 明化镇组 $\left(\mathrm{N}_{2} m\right)$ 发 育灰色泥岩夹砂岩, 为一套湖泊和河流三角洲相沉 积(图 2).

\section{2 不整合界面特征与盆地幕式裂陷作用}

\section{1 不整合面特征}

渤海湾新生代裂谷盆地, 发育了三个级别的不 整合. 一级不整合面是盆地同裂陷期地层顶、底之间 的不整合面，二级不整合面是裂陷幕之间的不整合 面，三级不整合面是局部不整合或沉积间断面.

一级不整合面为一级层序界面，是裂陷盆地顶、 底之间的全盆地普遍发育的规模较大的区域性角度 不整合界面. 其中古近系与前古近系之间的界面在 地震剖面上为 $\operatorname{Tr}$ 反射层. 该界面为一明显的角度不 整合(图 2,3). 其下伏地层表现为削截、侵蚀, 上覆地 层表现为上超(图 3(a)) 界面之下为古近系裂谷盆地的 基底, 界面之上为古近系同裂谷期沉积. 该界面之下 发育下白严统安山岩及火山碎屑岩, 具有典型的高 电阻测井曲线特征, 界面之上发育电阻率相对较低 的孔店组 $\left(\mathrm{E}_{1-2} k\right)$ 砾岩夹红色泥岩. 界面定年为 65 $\mathrm{Ma}^{[7,8]}$. 古近系与新近系之间的角度不整合面为 $\mathrm{T} 1$ 


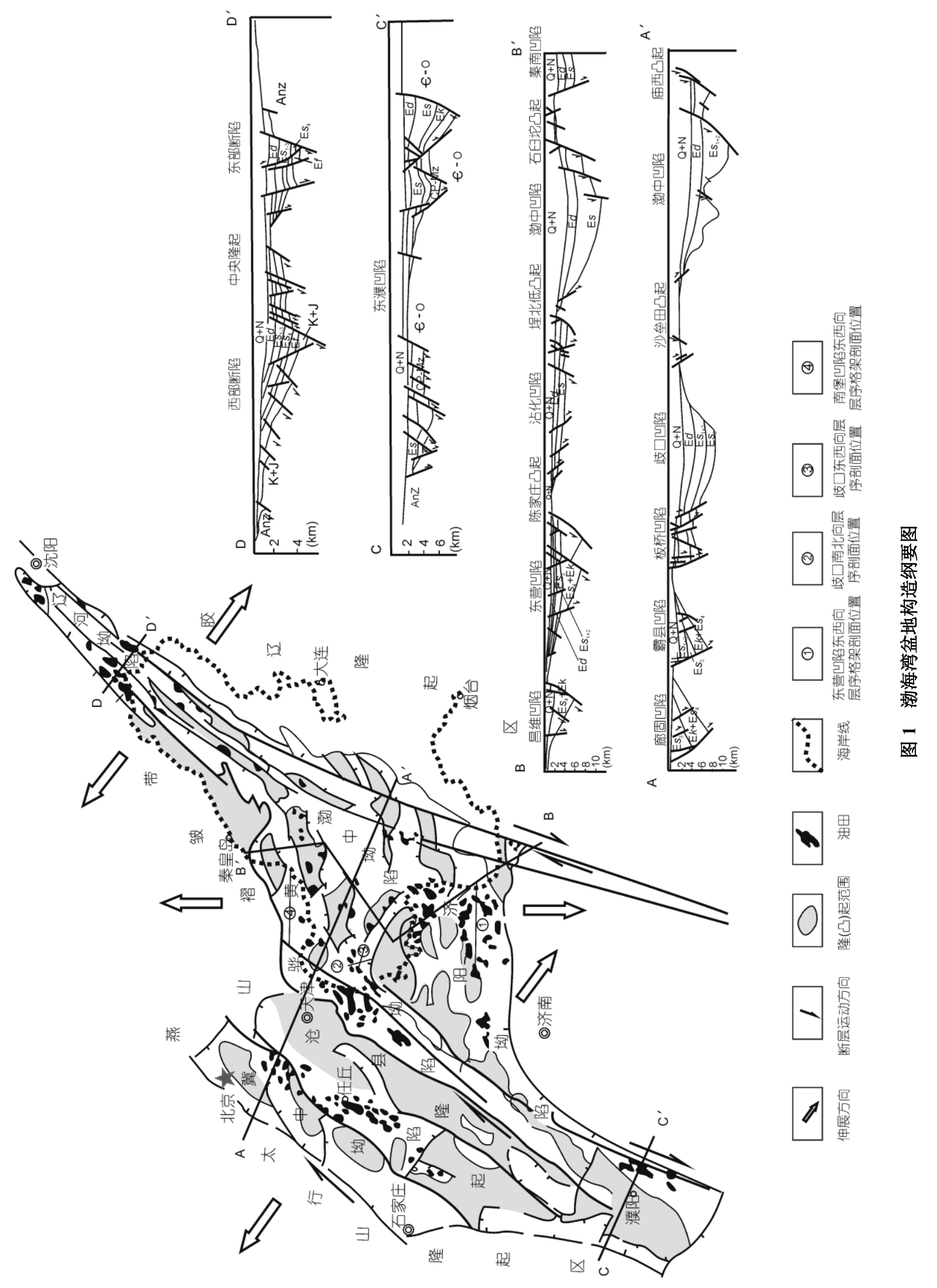




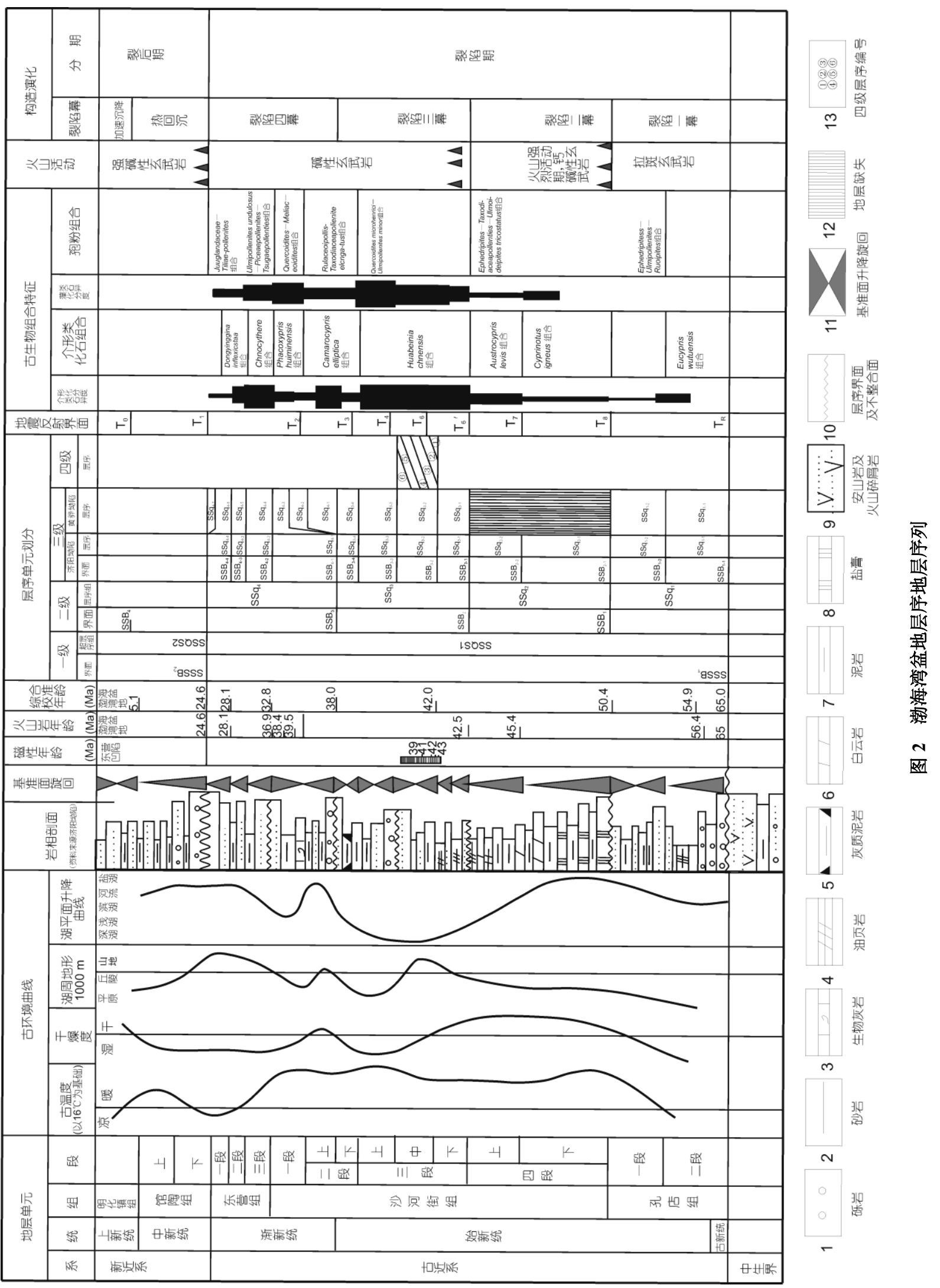


(a) 歧北 22

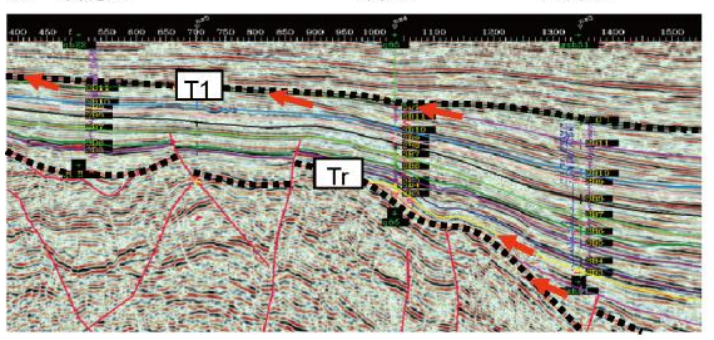

(c)

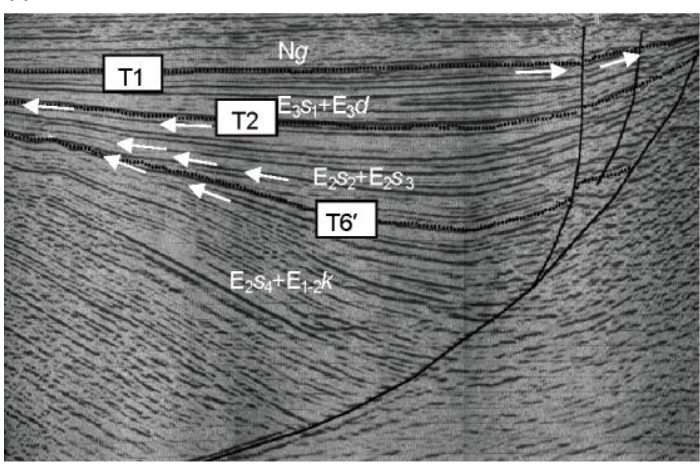

(b)

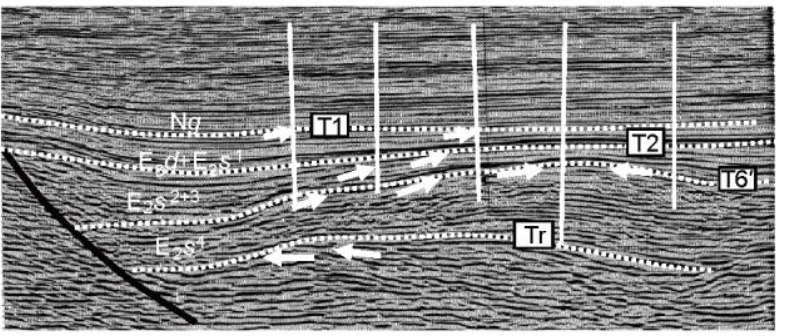

(d)

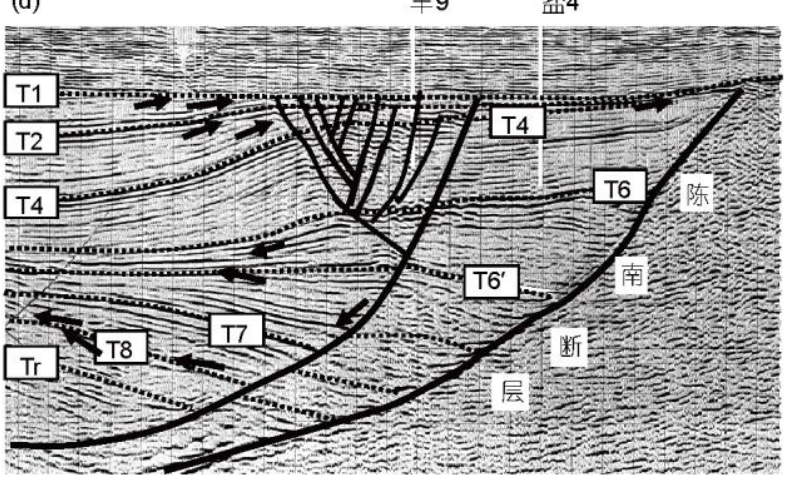

图 3 渤海湾盆地主要不整合界面地震反射特征

(a) 岐口凹陷东西向连井剖面; (b) 沾化凹陷渤南洼陷连井地震剖面; (c) 惠民凹陷阳信洼陷 518.9 测线; (d) 东营凹陷 626.6 测线南北向地震剖面

反射层(图 2,3). 该界面之下古近系同裂谷期为以砂 岩、含砾砂岩夹灰色泥岩为主的地层, 该界面之上为 渤海湾盆地普遍发育产状平缓的馆下段 $\left(\mathrm{N}_{1} g^{\mathrm{F}}\right)$ 厚层砾 岩、含砾粗砂岩夹薄层红色、灰绿色泥岩构成的正旋 回, 并伴随强碱性玄武岩和超基性岩喷发是后裂谷 期第一套沉积. 界面定年为 $24.6 \mathrm{Ma}^{[8,9]}$.

该不整合界面在地震反射剖面上表现为界面之 下呈削截反射特征, 界面之上呈上超或平行反射结 构. 在测井曲线上表现为界面之上为 “钟形” 自然电 位曲线, 界面之下为“指状”自然电位曲线和高电阻 率基值特征.

二级不整合面是仅次于一级不整合面的，规模 较大的全盆地可以对比的不整合面. 它们是裂陷幕 之间的区域性不整合面, 也是二级层序的界面. 在渤 海湾盆地古近系同裂谷期发育了 3 个二级不整合面. 它们是孔店组 $\left(\mathrm{E}_{1-2} k\right)$ 与沙四段 $\left(\mathrm{E}_{2} s_{4}\right)$ 之间的不整合面 (T8 反射界面), 沙三与沙四之间的不整合面(T6' 反射 界面), 沙二和沙一之间的不整合面(T2 反射界面)(图 2,3).

孔店组 $\left(\mathrm{E}_{1-2} k\right)$ 与沙四段 $\left(\mathrm{E}_{2} s_{4}\right)$ 之间的不整合面是 平行不整合 ( $\mathrm{T} 8$ 反射界面)在一些凹陷缺蚀, 这是因
为沙四段或孔店组在一些凹陷不发育所致. 如沾化 凹陷缺孔店组 $\left(\mathrm{E}_{1-2} k\right)$, 歧口凹陷缺沙四段 $\left(\mathrm{E}_{2} s_{4}\right)$. 该不 整合面(T8 反射界面)在地震反射剖面上表现为上超 和削截特征. 界面之下为棕红色泥岩与棕红色砂岩 互层，发育金星介(Cypris)-沼泽拟星介(Limnocythere) 组合. 界面之上发育灰色、紫红色、钙质泥岩夹石膏 层, 发育火红美星介组合(Cyprinotus igeneous). 在测 井曲线特征上表现为该不整界面之上为高电阻率特 征, 之下为低电阻率曲线特征.

沙三段 $\left(\mathrm{E}_{2} s_{3}\right)$ 与沙四段 $\left(\mathrm{E}_{2} s_{4}\right)$ 之间的不整合面( $\mathrm{T}^{\prime}{ }^{\prime}$ 反射界面)在渤海湾盆地普遍发育, 是一典型的角度 不整合, 界面两侧地层产状发生明显变化. 如惠民口 陷阳信洼陷 $\mathrm{T} 6^{\prime}$ 界面上下地层倾角下陡上缓, 东营凹 陷 T6'界面上下地层倾向相反, 沾化凹陷 $\mathrm{T} 66^{\prime}$ 界面上 下表现为明显的削截和超覆关系, 歧口凹陷缺沙四 段 $\left(\mathrm{E}_{2} s_{4}\right)$, 沙三段 $\left(\mathrm{E}_{2} s_{3}\right)$ 直接与白严系 $(\mathrm{K})$ 接触. 同时该 界面上下盆地基底沉降速率和伸展速率也发生了明 显变化. 如惠民凹陷阳信洼陷 $\mathrm{T} 6^{\prime}$ 界面之下沙四段 $\left(\mathrm{E}_{2} s_{4}\right)$ 的基底沉降速率大于 $\mathrm{T}^{\prime}$ 界面之上的沙三段 $\left(\mathrm{E}_{2} s_{3}\right)$. 东营凹陷和沾化凹陷在沙四段 $\left(\mathrm{E}_{2} s_{4}\right)$ 沉积之后 有一次挤压抬升, 使沙四段遭受剥蚀, 随后沙三段超 
覆其上(图 3(b), (d)) 形成 $\mathrm{T} 6^{\prime}$ 不整合面. 构造线在平面 上的走向在 $\mathrm{T} 6^{\prime}$ 界面上下也发生了显著变化. 如济阳 坳陷白严系 $(\mathrm{K})$ 到沙四段 $\left(\mathrm{E}_{2} s_{4}\right)(135 \sim 2.5 \mathrm{Ma})$ 控盆断 裂的走向为 $\mathrm{NW}$ 向, 地层的厚度中心也沿 $\mathrm{NW}$ 向断层
展布. 而沙三段 $\left(\mathrm{E}_{2} S_{3}\right)$-东营组 $\left(\mathrm{E}_{3} d\right)(42.5 \sim 24.6 \mathrm{Ma})$ 盆 地内主要活动断裂走向为 NE-NEE 向(图 4 和 5). 上 述特征表明 $\mathrm{T} 6^{\prime}$ 界面不但是二级不整合面, 也是盆地 构造活动和构造应力场的转化面.

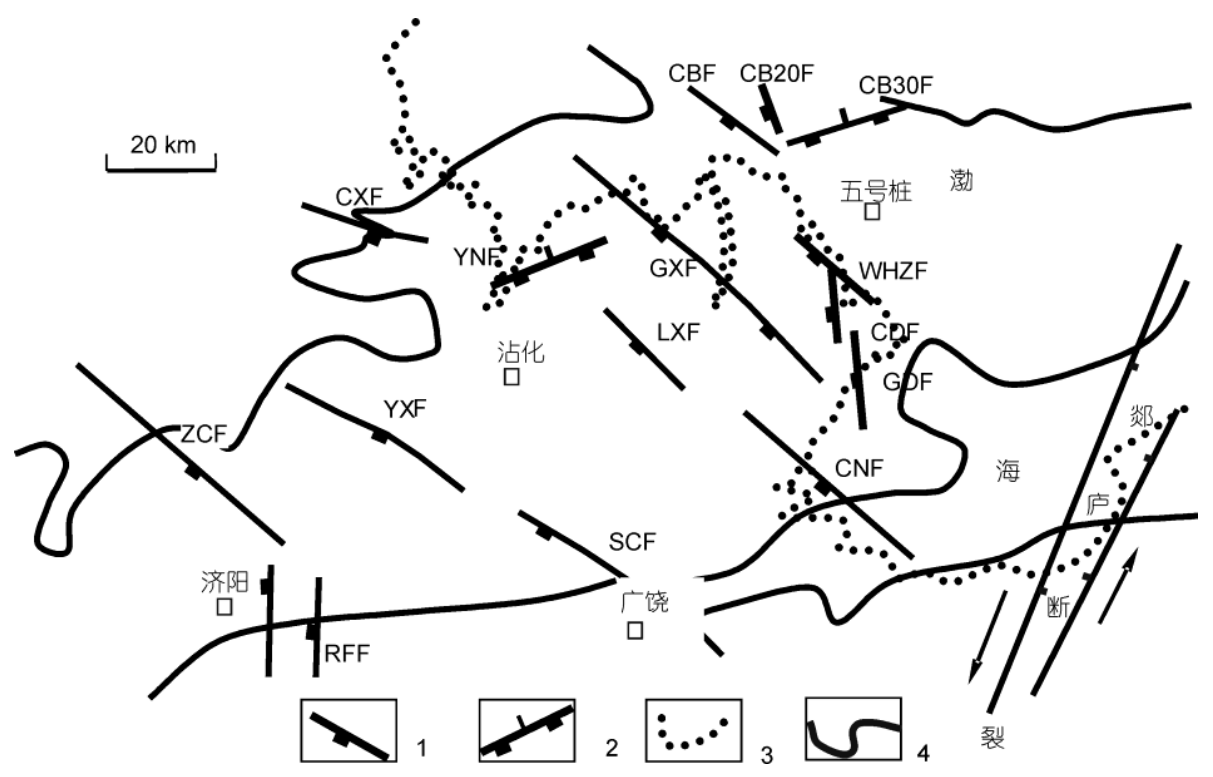

图 4 济阳咖陷白严系-沙四段控盆断分布图

据胜利油田资料. 135 42.5 Ma. 1, 正断层; 2, 逆冲断层; 3, 海岸线; 4, 济阳坳陷边界; CBF, 埕北断层; WHZF, 五号桩断层; GXF, 孤西断层; $\mathrm{CXF}$, 车西断层; $\mathrm{LXF}$, 罗西断层; $\mathrm{CNF}$, 陈南断层; SCF, 石村断层; YXF, 阳信断层; ZCF, 滋镇断层; CDF, 长堤断层; GDF, 孤东断层; $\mathrm{RFF}$ ，仁风断层; CB20F，埕北 20 断层; CB30F，埕北 30 断层; YNF，义南断层

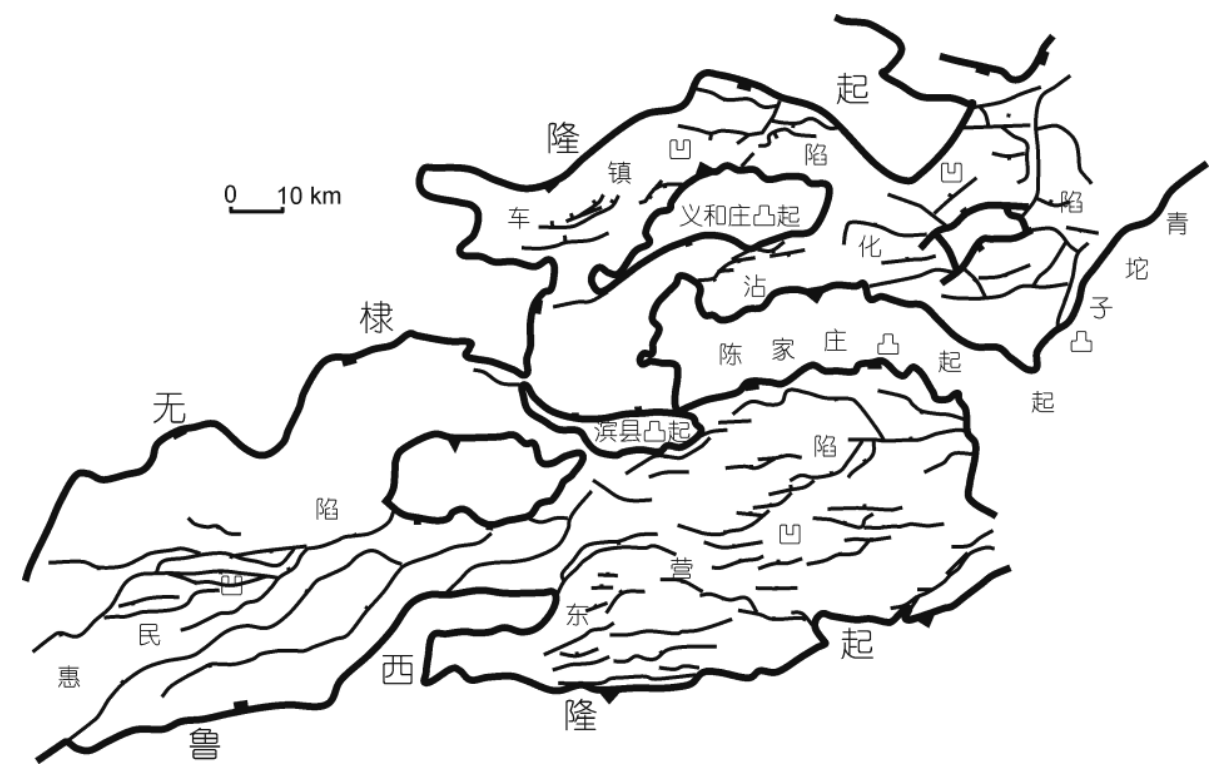

图 5 济阳坳陷沙三段-东营组(42.5 24.6 Ma)活动断裂分布图

据胜利油田资料 
在沾化、歧口等凹陷, T6'界面附近发育红色泥岩, 而在东营、辽河西部凹陷 $\mathrm{T} 66^{\prime}$ 界面上下从在着相序的 缺蚀. 另外在界面上下也存在着古生物组合的变化, 在 $\mathrm{T}^{\prime}$ 界面之下沙四上亚段 $\left(\mathrm{E}_{2} s_{4}{ }^{\llcorner}\right)$主要发育光滑南星 介组合(Austrocypris levis), $\mathrm{T}^{\prime}$ 界面之上沙三段 $\left(\mathrm{E}_{2} s_{3}\right)$ 主要发育华北介组合(Huabeinia).

沙一段与沙二段之间的不整合(黄骅坳陷，辽河 坳陷，冀中坳陷)或沙二上下之间(济阳坳陷)的不整 合(T2 地震反射界面)是一个区域性的角度不整合面. 在地震反射剖面上 $\mathrm{T} 2$ 界面之上为超覆, $\mathrm{T} 2$ 界面之下 为削截. 该不整合面之下沙二段或沙二下遭受了剥 蚀, 使其分布范围极为局限. 如歧口凹陷沙二段只残 留在歧北洼陷和歧南洼陷. 济阳坳陷沾化凹陷缺沙 二下. 在渤海湾盆地，该不整合面附近常发育砾岩夹 红色泥岩. 另外该界面上下古生物组合也不相同, 界 面之下发育拱星介(Camarolypris)组合, 界面之上发 育土星介(Ilyocyprimorpha) 组合. 该不整合面之上自 然电位曲线特征表现为“齿化箱状”或“齿化钟形”特 点. 界面之下则为“指状或线形”自然电位曲线特征.

三级不整合面是被二级不整合界面限制的地层 内发育的局部不整合和沉积间断面, 一般也是三级 层序的界面. 地震反射特征是在三级不整合之下发 育削截, 界面之上发育上超或下切水道充填所具有 的双向超覆反射结构(图 3(d)中的 T6 和 T4). 而在凹 陷中心一般为整合界面. 在测井和岩相特征上, 三级 界面一般为“钟形”自然电位(伽玛)所反映的具有冲刷 面的由砾岩、砂岩与泥岩构成的向上变细变薄正旋回 序列的底界面. 如水下扇、浊积扇及河道沉积的底界 面. “漏斗”形自然电位(伽玛)曲线所反映的向上变厚 变粗序列如三角洲前缘与 “齿化钟形”正旋回的河流 组合之间的界面，以及陆上暴露界面等(图 6).

渤海湾盆地上述三个级别不整合面分别代表了 三个级别的层序界面. 其中一级不整合面为超层序 组界面, 二级不整合为超层序界面, 三级不整合为层 序界面. 其不整合界面特征的不同是由其界面的规 模和性质决定. 一级、二级不整合面分别是古近系同 裂谷期和裂陷幕之间的区域性角度不整合. 这些界 面的形成与区域构造运动和盆地幕式裂陷作用有关, 发育规模较大. 这些界面上下属于不同的原形盆地 或裂陷充填幕, 其构造和沉积特征明显不同于相邻 原形盆地或裂陷充填幕. 一、二级不整合面上除发育 典型的区域不整合面上常见的底砾岩、红层、大型下
切谷特征外, 还伴有火山岩的喷发. 三级不整合面也 是三级层序界面，它们是局布发育的不整合和沉积 间断面, 与一、二级层序比较规模小、只在凹陷边缘 发育向凹陷中心过渡为整合面(图 3,6).

\section{2 古近系盆地幕式裂陷作用}

根据古近系同裂谷期内发育的二级区域不整合 面、沉积旋回、构造沉降和构造岩浆发育特征, 渤海 湾盆地古近系同裂谷期可划分为四幕裂陷.

裂陷一幕由孔店组 $\left(\mathrm{E}_{1-2} k\right)$ 构成，其底界面为古近 系与前古近系之间的角度不整合 $(\mathrm{Tr}$ 反射界面), 顶界 面为孔店组 $\left(\mathrm{E}_{1-2} k\right)$ 与沙四段 $\left(\mathrm{E}_{2} s_{4}\right)$ 之间的不整合 $(\mathrm{T} 8$ 反 射界面). 该套地层在沉积组合上表现为底部发育红 色粗碎屑沉积, 中下部发育灰色湖泊沉积, 上部发育 红色碎屑岩沉积, 构成了湖泊由扩张到萎缩的完整 旋回. 并伴随着拉斑玄武岩的喷发. 构造沉降史分析 表明该裂陷幕盆地基底沉降速率相对较高, 如济阳 坳陷(东营凹陷)基底沉降速率达到 $110 \mathrm{~m} / \mathrm{Ma}$ (图 7), 地层厚度中心沿 $\mathrm{NW}$ 向断裂展布, NE-SW 向伸展是 其主要特征(图 4). 辽河坳陷房身泡组 $\left(\mathrm{E}_{1-2} f\right)$ 地层沿 $\mathrm{NE}$ 向控盆断裂展布, NW-SE 向伸展是其主要特征.

裂陷二幕由沙四段 $\left(\mathrm{E}_{2} s_{4}\right)$ 构成，顶界面为沙四段 $\left(\mathrm{E}_{2} s_{4}\right)$ 与沙三段 $\left(\mathrm{E}_{2} s_{3}\right)$ 之间的不整合 ( $\mathrm{T} 6^{\prime}$ 反射界面). 该 套地层在岩石组合上表现为下部发育红色粗碎屑和 蒸发岩, 中部发育湖相暗色沉积, 上部发育粗碎屑的 河流、三角洲沉积. 构成了湖泊由扩张到萎缩的完整 旋回. 并伴随着钙碱性玄武岩喷发. 盆地基底沉降和 构造伸展速率分析表明该裂陷幕盆地基底沉降和构 造伸展速率较裂陷一幕有所变化. 如东营凹陷盆地 基底总沉降速率为 $90 \mathrm{~m} / \mathrm{Ma}$ ，构造沉降速率 $50 \mathrm{~m} / \mathrm{Ma}$. 沾化凹陷盆地基底总沉降速率为 $140 \mathrm{~m} / \mathrm{Ma}$ ，构造沉 降速率 $110 \mathrm{~m} / \mathrm{Ma}$ (图 7). 裂陷一幕和裂陷二幕 $\mathrm{NW}$, $\mathrm{NE}$ 向断裂活动，并在不同的坳陷活动形式略有差异. 位于沧县隆起以西的冀中坳陷和位于秋庐断裂带中 的下辽河坳陷，以 $\mathrm{NE}$ 向断裂活动为主，并控制地层 的发育. 位于盆地东南部的济阳坳陷和渤海海域的 渤中坳陷以北西向断裂活动为主并控制地层的展布 (图 1,4,5).

裂陷三幕由沙三段 $\left(\mathrm{E}_{2} s_{3}\right)$ 到沙二段 $\left(\mathrm{E}_{2} s_{2}\right)$ 构成，其 顶界面为沙二 $\left(\mathrm{E}_{2} s_{2}\right)$ 与沙一 $\left(\mathrm{E}_{3} s_{1}\right)$ 之间的不整合 $(\mathrm{T} 2$ 反 射界面)。该套地层在岩石组合上表现为底部发育粗 碎屑，中下部发育厚度巨大的暗色泥岩夹浊积岩组 

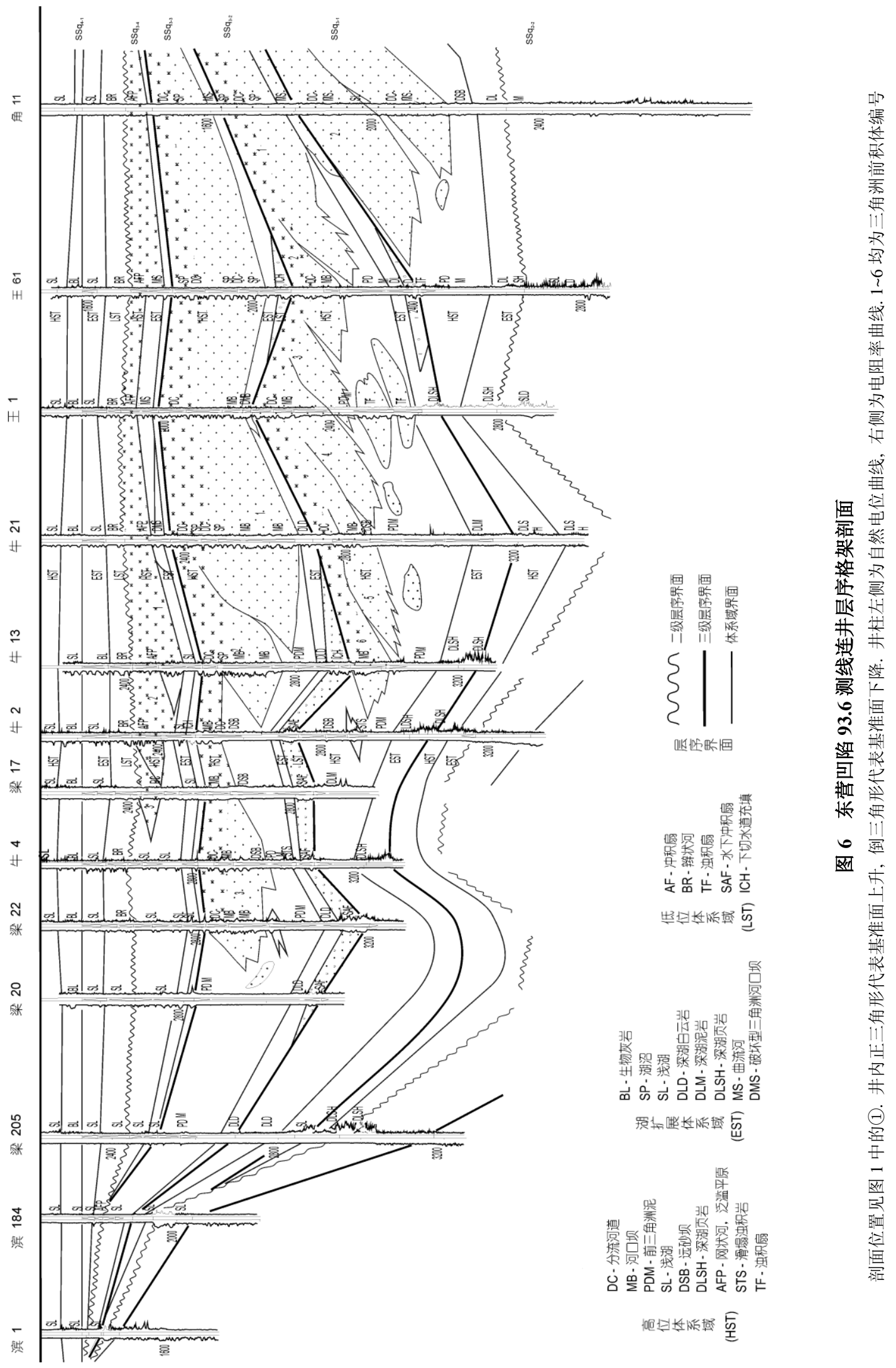

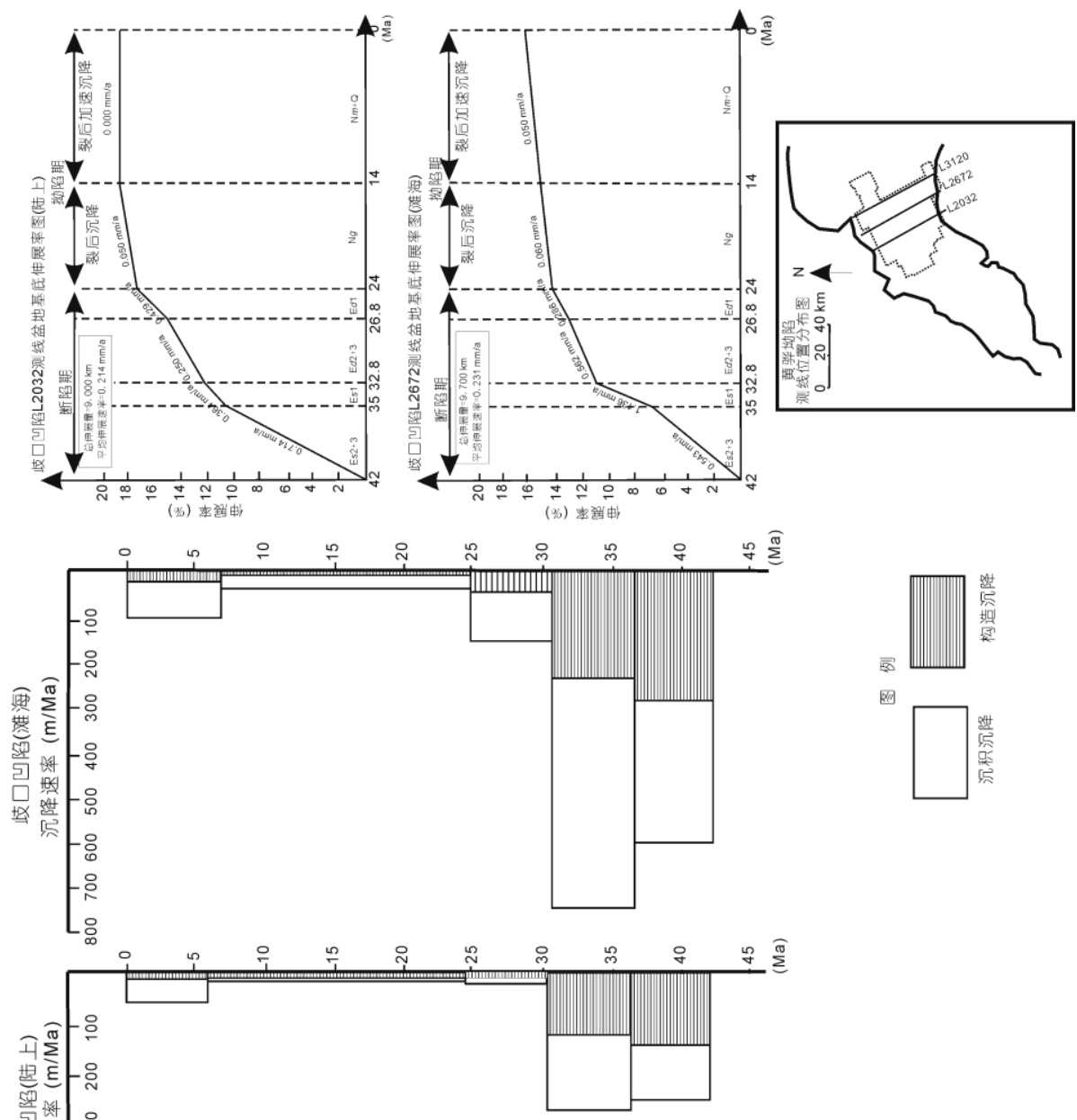

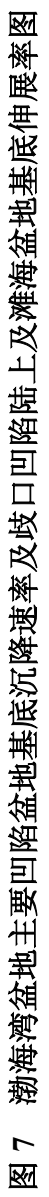

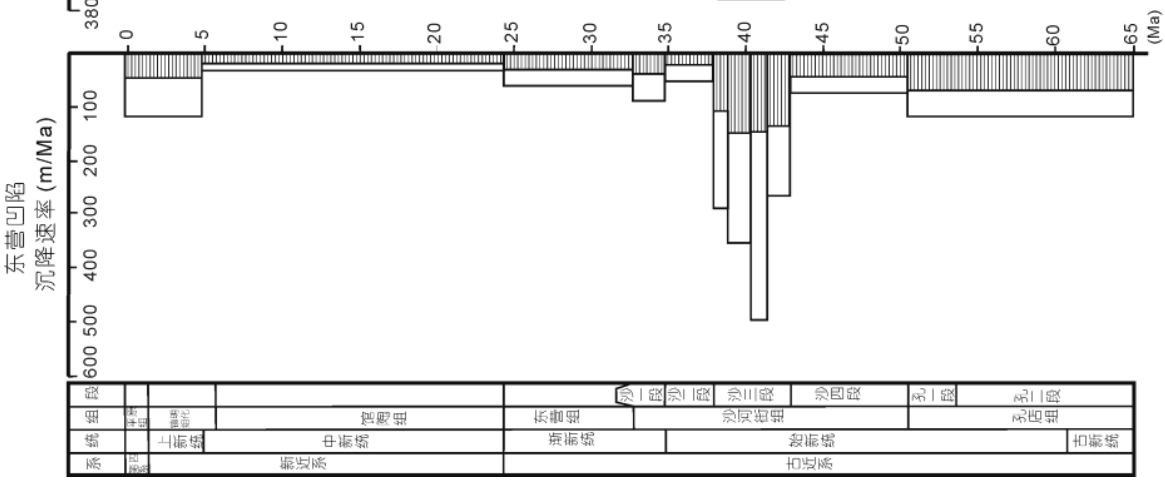


合, 上部发育粗碎屑河流三角洲沉积, 构成了湖泊由 快速扩展到缓慢萎缩的旋回. 并伴随着强烈的碱性 玄武岩的喷发. 该套地层在渤海湾盆地广泛发育, 厚 度约 1000 1500 m, 是一套以发育厚层暗色泥岩及河 流三角州沉积为主的, 具有典型前积结构的地层叠 加样式的沉积建造, 代表了渤海湾盆地强烈裂陷幕 的构造沉积组合. 据盆地基底沉降和构造伸展速率 分析, 该裂陷幕盆地基底沉降速率和伸展速率在渤 海湾陆上各坳陷达到最大值. 其中济阳坳陷东营凹 陷基底沉降速率达 300 550 m/Ma, 沾化凹陷盆地基 底沉降速率达 $350 \mathrm{~m} / \mathrm{Ma}$; 下辽河坳陷盆地基底沉将 速率达 $264 \mathrm{~m} / \mathrm{Ma}$, 下辽河坳陷基底伸展速率达 727 $\mathrm{m} / \mathrm{Ma}^{[10]}$; 黄骅坳陷歧口凹陷盆地基底沉降速率达 300 600 m/Ma, 盆地基底伸展速率达 534 714 m/Ma. 该裂陷幕 NE, NEE 向伸展断裂控制地层的展布, 盆 地发育 SN 向及 NW-SE 向伸展是其主要特征(图 5,7).

裂陷四幕由沙一段 $\left(\mathrm{E}_{3} s_{1}\right)$ 和东营组 $\left(\mathrm{E}_{3} d\right)$ 构成, 顶 界面为古近系与新近系之间的不整合( T1 地震反射界 面). 该套地层在岩石组合上表现为底部发育粗碎屑 岩夹红色泥岩, 中下部发育灰色泥岩夹灰岩的湖相 沉积, 上部发育粗砂岩夹泥岩的河流三角相沉积体 系, 构成了湖盆由扩展到萎缩的完整旋回. 该套地层 分布广泛, 在渤海湾盆地陆上厚度较小约 500 800 m, 在滩海及海域沉积厚度达 1000 1800 m. 构成了发育 暗色泥岩、灰色泥岩及砂泥互层为主的以垂向加积和 侧向进积为特征的地层叠加形式. 据盆地基底沉降 速率和伸展速率分析, 该裂陷幕盆地基底沉降和伸 展速率在陆上各凹陷明显减小, 如东营凹陷盆地基 底沉降速率为 $50 \mathrm{~m} / \mathrm{Ma}$. 沾化凹陷盆地基底沉降速率 为 70 100 m/Ma. 辽河凹陷盆地基底沉降速率为 52.8 $\mathrm{m} / \mathrm{Ma}$, 盆地基底伸展速率为 $22.6 \mathrm{~m} / \mathrm{Ma}^{[10]}$. 相反在渤 海湾滩海及海域盆地基底沉降速率和构造伸展速率 加大, 如下辽河滩海盆地沙一段 $\left(\mathrm{E}_{3} s_{1}\right)$ 基底沉降速率 为 $163.9 \mathrm{~m} / \mathrm{Ma}$, 盆地基底伸展速率为 $72.8 \mathrm{~m} / \mathrm{Ma}$, 东 营组 $\left(\mathrm{E}_{3} d\right)$ 基底沉降速率为 $89.1 \mathrm{~m} / \mathrm{Ma}$, 盆地基底伸展 速率为 $38.2 \mathrm{~m} / \mathrm{Ma}^{[10]}$. 歧口凹陷滩海地区沙一段 $\left(\mathrm{E}_{3} \mathrm{~s}_{1}\right)$ 盆地基底沉降速率高达 $740 \mathrm{~m} / \mathrm{Ma}$, 伸展速率达 1136 $\mathrm{m} / \mathrm{Ma}$; 东营组 $\left(\mathrm{E}_{3} d\right)$ 盆地基底沉降速率 $180 \mathrm{~m} / \mathrm{Ma}$, 基 底伸展速率 $562 \mathrm{~m} / \mathrm{Ma}$ (图 7). 该裂陷幕 NE, NEE 向断 裂伸展作用在陆上减弱, 而在渤海海域及滩海地区 断裂伸展和右行走滑作用增强.

新近系馆陶组 $\left(\mathrm{N}_{1} g\right)$ 和明化镇组 $\left(\mathrm{N}_{1} m\right)$ 整个渤海
湾盆地基底沉降速率减小到 $30 \mathrm{~m} / \mathrm{Ma}$ 以下(图 7), 盆 地进入了整体拗陷或热沉降阶段. 渤海湾盆地普遍发 育了一套由粗砾岩、中砾岩、粗砂岩夹紫红色灰绿色 泥岩构成的向上变细的正旋回辨状河及曲流河沉积.

由于渤海湾盆地古近系同裂谷期盆地在不同的 坳(凹)陷其构造活动的差异性, 必然造成各裂陷幕及 不整合面发育的程度不同. 东营凹陷、沾化凹陷、歧 口凹陷及辽河西部凹陷一级、二级、三级不整合面对 比关系及各裂陷幕发育特征见图 8. 其基本特征是一 级、二级不整合面发育位置基本一致, 三级不整合面 发育个数在不同凹陷梢有差异. 四个裂陷幕在东营、 辽河西部凹陷均较发育, 沾化凹陷缺裂陷一幕, 歧口 凹陷缺裂陷二幕(图 8 ).

\section{3 层序地层格架及体系域构成特征}

裂谷盆地层序地层序列是盆地及其幕式构造发 展和主控断裂幕式构造活动的产物 ${ }^{[1]}$. 裂谷盆地同 裂谷期(Syn-rift)和后裂谷期(Post-rift)地层序列分别 属于不同的构造背景. 前者以裂陷作用为主, 发育伸 展构造及其沉积组合, 后者以热沉降作用为主, 发育 简单拗陷构造及其沉积组合. 因此裂谷盆地同裂谷 期和后裂谷期地层序列应分别属于不同的高级别层 序. Hubbard ${ }^{[12]}$ 和 William ${ }^{[13]}$ 在研究了发育裂陷的大陆 边缘盆地后, 把同裂谷期和裂后期地层分别划归为 不同巨层序(Megasequence). 渤海湾盆地的作为一个 早衰的中新生代裂谷盆地, 其同裂谷陷期 $\left(\mathrm{E}_{1-2} k-\mathrm{E}_{3} d\right)$ 和后裂谷期 $\left(\mathrm{N}_{1} g-\mathrm{Q}\right)$ 地层发育的时限分别大约为 40 和 $24 \mathrm{Ma}$, 故本文把该盆地的同裂谷期和后裂谷期地层 划归为不同的超层序组. 裂陷期内发育的多幕裂陷 对应的地层序列分别属于不同的超层序. 然后在超 层序内再识别三级层序, 以及三级层序内发育的四 级层序等(图 2).

\section{1 层序地层序列}

按照上述地层划分原则, 渤海湾盆地古近纪同 裂谷期地层为超层序组 1 (SSQS1), 新近纪后裂谷期 地层为超层序组 2(SSQS2). 同裂谷期发育的四幕裂 陷对应的地层序列分别相当于四个超层序(SSq). 超 层序 1 对应裂陷 1 幕由孔店组 $\left(\mathrm{E}_{1-2} k_{1}\right)$ 构成, 超层序 2 对应裂陷 2 幕由沙四段 $\left(\mathrm{E}_{2} s_{4}\right)$ 组成, 超层序 3 对应裂陷 3 幕由沙三段 $\left(\mathrm{E}_{2} s_{3}\right)$-沙二段 $\left(\mathrm{E}_{2} s_{2}\right)$ 组成, 超层序 4 对应 


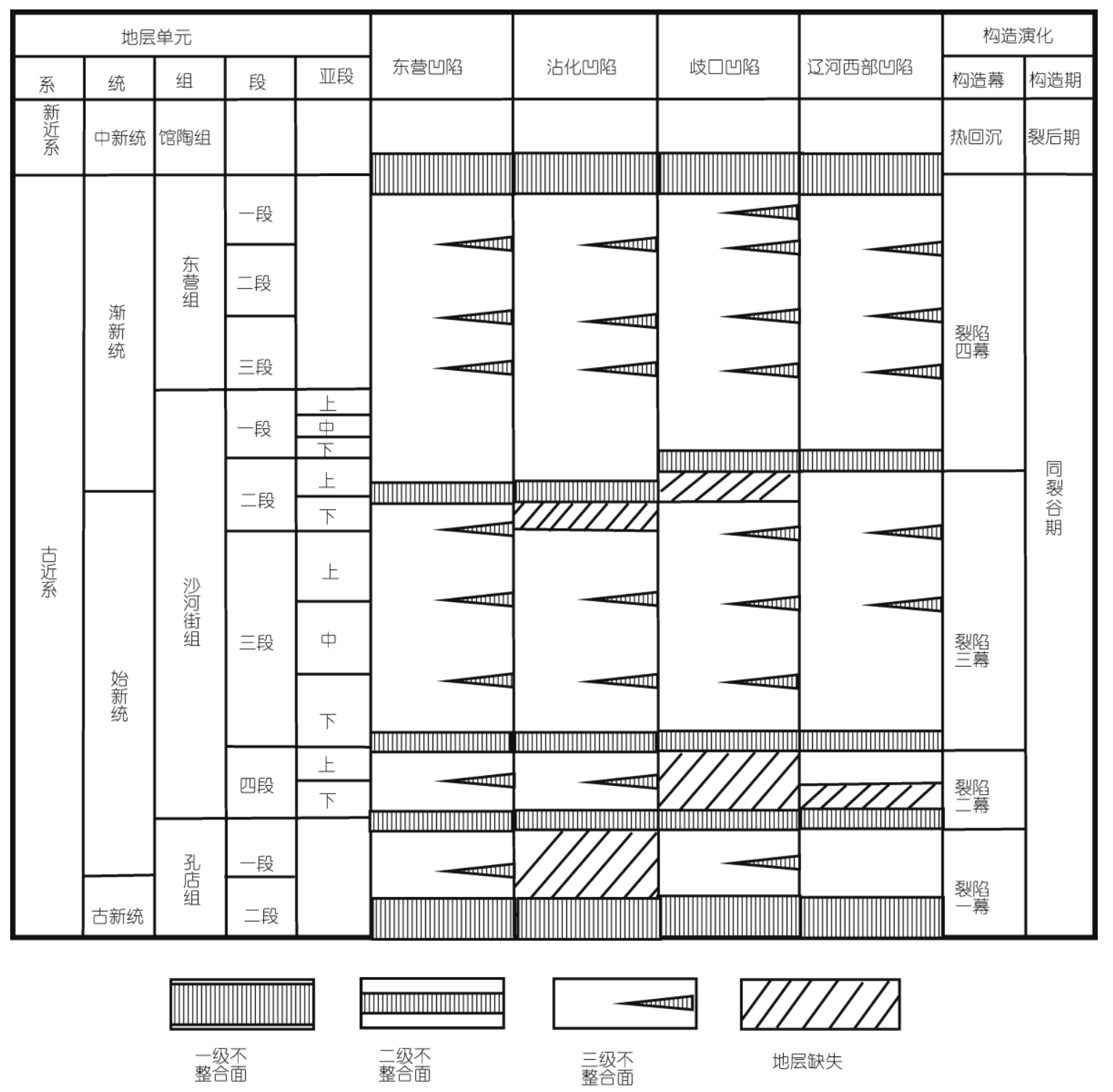

图 8 渤海湾盆地东部主要凹陷不整合面及地层发育对比图

裂陷 4 幕由沙一段 $\left(\mathrm{E}_{3} s_{1}\right)$-东营组 $\left(\mathrm{E}_{3} d\right)$ 组成. 古近系超 层序组、超层序在渤海湾盆地各坳陷具有可对比性 (图 8). 在每个超层序内部, 根据三级层序界面(三级 不整合面)发育特征，可以划分出不同的三级层序. 如济阳坳陷东营凹陷, 在古近系超层序组内发育了 四个超层序, 超层序 1 和超层序 2 分别发育 2 个三级 层序, 超层序 3 和超层序 4 分别发育 4 个三级层序. 在超层序 3 发育的三级层序还可以划分出 4 级层序. 沾化凹陷缺超层序 1 , 超层序 2 发育两个三级层序, 超层序 3 发育三个三级层序, 超层序 4 发育 4 个三级 层序. 黄骅坳陷歧口凹陷, 古近系超层序组发育超层
序 1 、超层序 3 和超层序 4 , 缺超层序 2 . 超层序 1 发 育 1 个三级层序, 超层序 3 和超层序 4 分别发育 4 个 和 7 个三级层序. 辽河坳陷西部凹陷, 古近系 4 个超 层序均发育, 其中超层序 1 和超层序 2 各发育 1 个三 级层序, 超层序 3 发育 3 个三级层序, 超层 4 发育四 个三级层序(图 2,8).

与孔店组 $\left(\mathrm{E}_{1-2} k_{1}\right)$ 和沙四段 $\left(\mathrm{E}_{2} s_{4}\right)$ 对应的超层序 1 和超层序 2 , 为初始裂陷背景、干旱气候条件下的湖 泊沉积组合, 为水平加积层序沉积序列. 与沙三 $\left(\mathrm{E}_{2} s_{3}\right)$-沙二 $\left(\mathrm{E}_{2} s_{2}\right)$ 对应的超层序 3 代表了盆地主裂陷 幕断裂活动强烈，发育深湖浊积扇、水下扇、扇三角 
洲及河流三角洲沉积体系为主的层序. 由于断裂活 动和沉积中心的迁移, 导致了三级层序在纵向剖面 上具有侧向加积的层序叠加特征 (图 6). 与沙一 $\left(\mathrm{E}_{3} s_{1}\right)$-东营组 $\left(\mathrm{E}_{3} d\right)$ 对应的超层序 4 代表了裂陷 4 幕断 陷作用减弱, 在宽缓盆地背景上发育的以浅湖、三角 洲和河流沉积体系为主的层序, 这些三级层序具有 垂向加积的地层序列特征.

\section{2 层序形式及体系域构成特征}

渤海湾盆地古近系同裂谷期断陷盆地层序地层 的发育是盆地构造运动、古气候、沉积物供给共同作 用的结果. 在不同的构造幕和同一构造幕的不同构 造部位发育的层序体系域构成特征不同 ${ }^{[14]}$. 对于一 个简单的箕状断陷而言，位于陡坡控盆断裂下降盘、 断层调节带、缓坡断阶带等部位的层序体系域构成特 征各不相同 ${ }^{[15,16]}$. Vail 等 ${ }^{[17]}$ 把同沉积断裂较发育的被 动大陆边缘作为一种独立类型与具有陆架坡折的 $\mathrm{I}$ 型 层序并列, Howell 和 Flint ${ }^{[15]}$ 认为伸展盆地中的同沉 积断裂和断层转换带其作用等同于被动大陆边缘的 陆架坡折. 我国学者在对济阳坳陷古近系层序发育 与同沉积构造关系研究的基础上明确提出了同沉积 构造坡折带的概念 ${ }^{[5]}$, 对构造坡折带形式进行了划分, 并以同沉积构造坡折带的形式作为陆相断陷盆地层 序形式划分的主要依据. 研究表明渤海湾盆地古近 系同裂谷期主要发育了同沉积断裂坡折带、同沉积挠 曲构造坡折两类构造坡折带和无坡折的缓坡三种层 序发育背景及其层序形式 ${ }^{[18]}$. 就同以层序而言, 不同 的坡折背景具有不同的层序形式.

\subsection{1 同沉积断裂坡折(背景)层序形式}

渤海湾断陷盆地古近系同裂谷期发育同沉积断 裂及其断裂坡折带是其基本特征之一. 同沉积断裂 坡折带控制层序及体系域的发育.

以黄骅坳陷岐口凹陷为例, 在南北向地震一连 井层序格架剖面上, 岐北洼陷的北大港陡坡断裂带, 岐南洼陷的南大港陡坡断裂带以及埕北缓坡断阶带, 同沉积断裂坡折带发育, 并控制层序和体系域的发 育. 主要表现为断裂坡折带之下的港深 25 、岐南 2 层序低位域砂体极为发育, 湖扩展体系域, 高位域厚 度较大. 而在坡折带之上层序低位域不发育, 湖扩展 体系域, 高位域厚度减薄(图 9).

通过对渤海湾盆地岐口、南堡、东营、沾化、西
部凹陷古近系超层序 3 同沉积断裂坡折背景下, 受沉 积断裂坡折控制的层序体系域构成特征的研究表明， 同沉积断裂坡折制的层序具有如下特征：断裂坡折 之上层序较薄, 而断裂坡折带之下层序较厚. 断裂坡 折之上层序低位域不发育或只发育下切水道充填、辫 状河，而断裂坡折带之下层序低位域普遍发育低位 三角洲、水下扇或浊积扇. 湖扩展体系域在构造坡折 带之下主要为一套稳定的深湖相泥岩、油页岩. 在陡 坡断裂坡折带之上主要发育湖进型扇三角洲或砾质 滨岸沉积. 在缓坡断裂坡折带之上主要发育滨浅湖 或湖进型三角洲沉积. 高位域在陡坡主要发育扇三 角洲体系, 在缓坡轴向主要发育河流三角洲沉积体 系(图 10).

盆地裂陷 1,2 幕对应的超层序 1 和 2 同样也发育 同沉积断裂坡折控制的层序，但体系域构成特征不 同. 其低位域主要发育在同沉积断裂坡折之下，以发 育冲积扇和辫状河为主. 湖扩展体系域主要发育滨 浅湖, 小型三角洲、扇三角洲, 高位域发育冲积扇、 扇三角洲及盐湖沉积.

\subsection{2 同沉积挠曲坡折(背景)层序}

同沉积挠曲构造坡折(背景)层序是同裂谷期局 部发育的另一种层序形式. 它常发育在裂陷 3 幕及 4 幕对应的超层序 3, 4. 同沉积挠曲构造坡折带常发育 在同沉积背斜构造的斜坡、掀斜构造运动强烈的半地 堑凹陷的缓坡及基底断裂差异活动强烈的斜坡带.

在岐口凹陷孔店凸起的斜坡部位(图 11), 南堡凹 陷陡坡后期断裂差异沉降部位就发育同沉积挠曲坡 折带(图 12).

歧口凹陷孔店凸起斜坡带地震一一连井层序格 架剖面分析表明, 在挠曲坡折带上、下层序厚度变化 明显. 主要表现为挠曲坡折带之下的岐 85、港深 51、 港深 48 等井低位域除个别层序外均较发育. 湖扩展 体系域和高位域厚度较大. 挠曲坡折之上层序低位 域不发育或在局部发育下切河道, 湖扩展体系域和 高位域厚度减小(图 11). 南堡凹陷挠曲坡折带上、下 层序厚度变化特征及体系域发育特征与歧口凹陷孔 店斜坡相同(图 12).

通过对渤海湾盆地岐口、南堡等发育挠曲坡折的 层序体系域构成特征的研究表明，挠曲坡折控制的 层序其坡折部位(脊线和槽线之间)由早到晚向凹陷 的沉降中心迁移(图 11，12). 坡折带之下低位域发育 

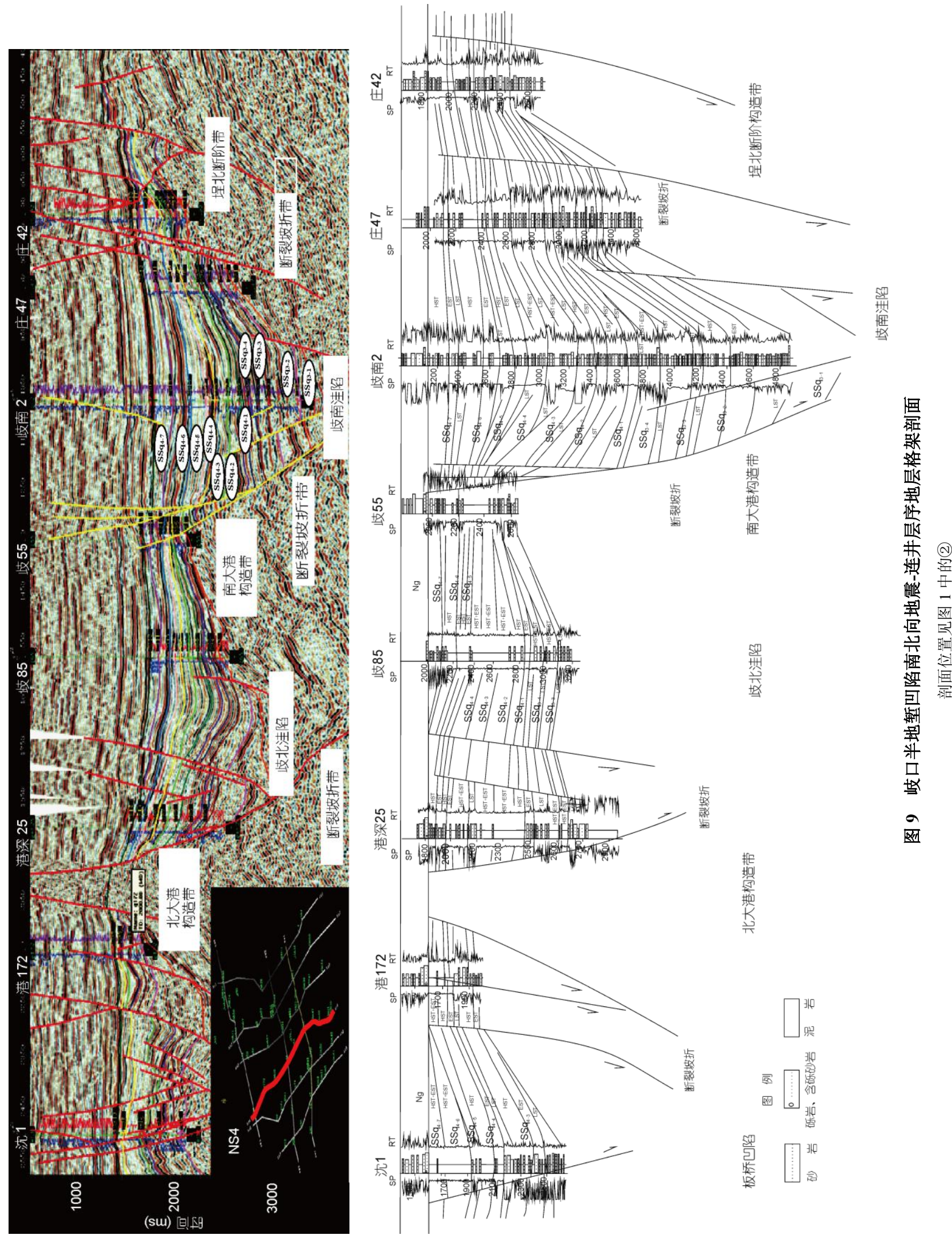

1368 


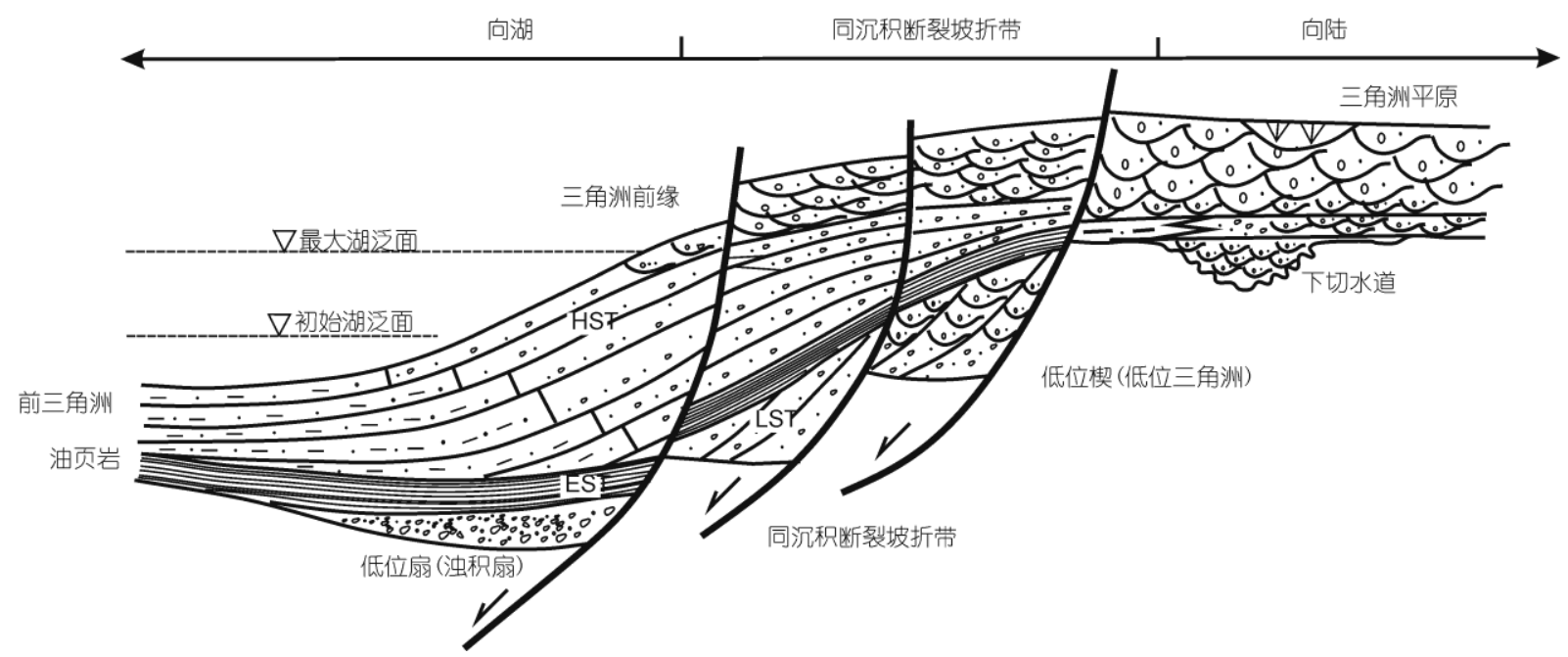

图 10 同沉积断裂坡折(背景)层序体系域构成模式

低位扇三角洲、浊积扇, 坡折带之上低位域主要发育 下切河谷充填砂体. 湖扩展体系域在挠曲坡折带之 下主要发育深湖、半深湖沉积, 在坡折之上主要发育 滨浅湖沉积. 高位域主要发育进积型滨浅湖及河流 三角洲沉积(图 13).

\subsection{3 缓坡(背景)层序}

渤海湾盆地裂陷 4 幕陆上各凹陷及新近纪拗陷 期, 由于构造活动减弱或趋于稳定, 形成较平缓的斜 坡构造背景. 在该平缓斜坡背景下发育的层序体系 域特征明显不同于有构造坡折的层序形式. 如渤海 湾盆地新近系馆陶组 $\left(\mathrm{N}_{1} g\right)$ 层序, 歧口凹陷的 $\mathrm{SSq}_{4-7}$ 层序(图 9), 南堡凹陷的 $\mathrm{SSq}_{4-1} \sim \mathrm{SSq}_{4-4}$ 层序(图 12). 其 低位体系域(LST)为平缓斜坡背景上发育的冲积扇、 辫状河道或水下扇. 其湖扩展体系域(EST)为半深湖 泥岩、滨浅湖沉积. 高位域(HST)主要为河流-三角洲 或滨浅湖沉积(图 14). 在新近系盆地坳陷期平缓斜坡 背景下发育的层序中 (馆陶组 $\left(\mathrm{N}_{1} g\right)$ 层序), 缺高位域 (HST) 而只发育以冲积扇和辫状河为主的低位域 (LST)和以发育泛滥平原为主的湖扩展域(EST), 构 成所谓的河流冲积型层序 ${ }^{[19]}$.

\section{3 低位域砂体的发育特征及其石油地质意义}

盆地裂陷三幕发育的层序其低位域主要发育下 切水道充填砂体、低位楔(低位三角洲)砂体、低位扇 (低位水下扇、浊积扇等)砂体 ${ }^{[20]}$. 由于低位域砂体发 育在湖域范围相对较小, 砂体能被较强的水动力搬
运到湖盆中心位置，在同沉积断裂及挠曲坡折带之 下形成低位楔和低位扇砂体，在同沉积断裂及挠曲 坡折带之上发育下切水道充填砂体, 这些低位域砂 体储层物性好, 其分布受同沉积构造坡折带的控制. 随后而来的湖扩展优质烃源岩覆盖其上，形成上生、 下储良好的储盖组合. 同时深部生成的油气也能沿 坡折断裂向上运移，使得层序低位域砂体成藏条件 良好, 为岩性油气藏勘探的主要目标.

以东营凹陷为例，超层序 3 发育的三个层序低位 域砂体的分布受同期活动同沉积断裂坡折带的控制. 早期凹陷陡坡和缓坡边缘部位同沉积断裂坡折带发 育, 早期的 $\mathrm{SSq}_{3-1}$ 和 $\mathrm{SSq}_{3-2}$ 层序低位域(LST)砂体就发 育在这些同沉积断裂坡折带之下，沿同沉积断裂坡 折展布. 晚期同沉积断裂坡折带向凹陷中心迁移, $\mathrm{SSq}_{3-3}$ 层序底位砂体也向凹陷中心迁移, 低位扇和低 位楔砂体主要发育在同沉积断裂坡折之下沿其分布, 下切水道砂体发育在同沉积断裂坡折之上(图 15). 超 层序 3 对应于裂陷三幕, 其湖扩展体系域泥岩均为优 质烃源岩, 发育在其下的底位域砂体非常有利于形 成岩性油气藏. 因此每个层序受同沉积断裂坡折带 控制并沿其分布的低位域砂体就是岩性油气藏勘探 的目标砂体.

按照寻找构造坡折带控制下的低位域砂体岩性 油气藏的勘探思路, 在东营凹陷北陡坡断阶状坡折 带发现了 $\mathrm{SSq}_{3-1}$ 层序坨 71, 719 低位楔、低位扇含油 砂体. 在车镇凹陷北陡坡坡折带发现了 $\mathrm{SSq}_{4-2}$ 层序车 57 低位扇含油砂体. 在惠民凹陷南缓坡坡折带发现 

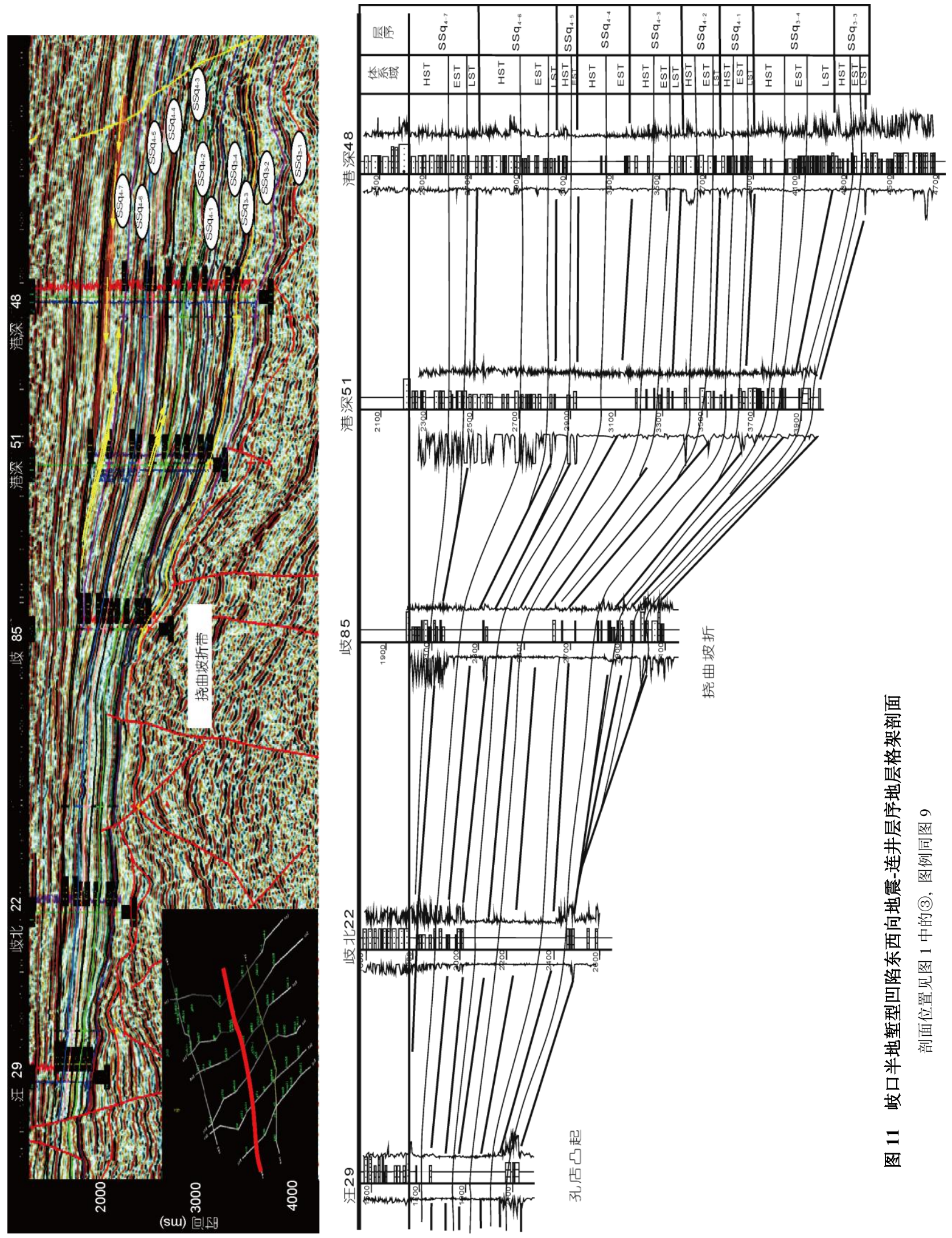


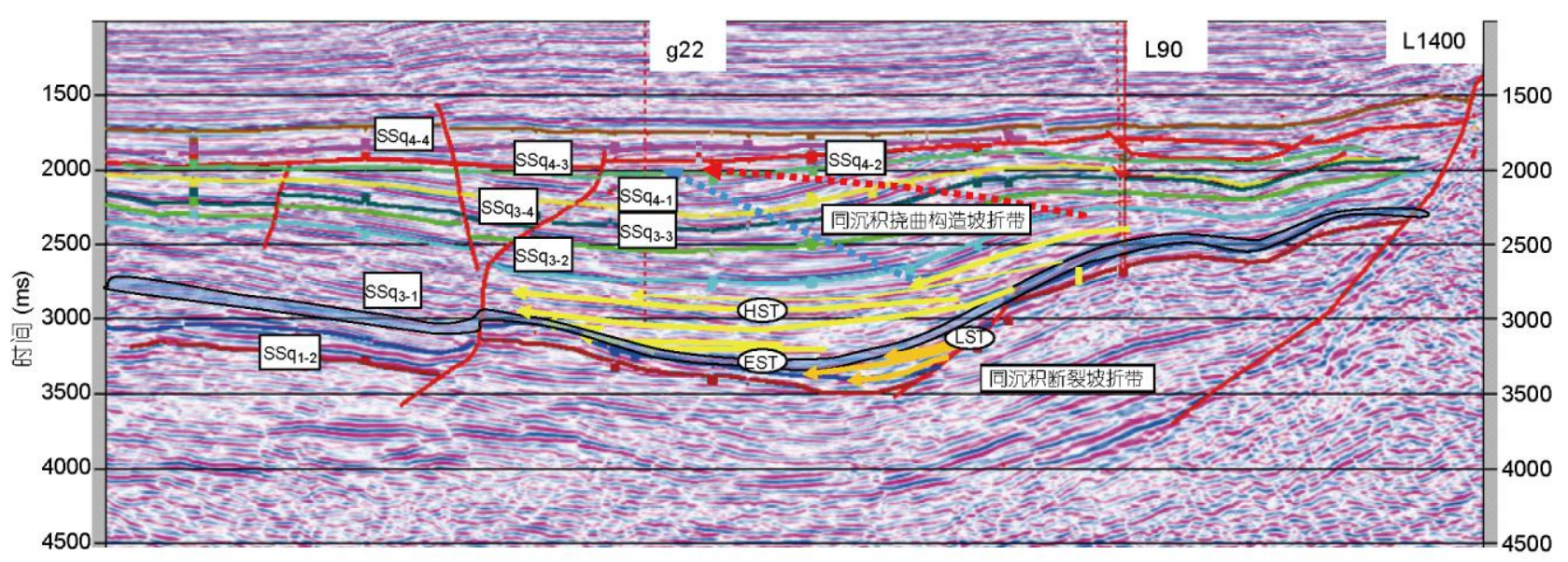

图 12 南堡凹陷 L1400 测线地震剖面层序解释

剖面位置见图 1 中的(4)

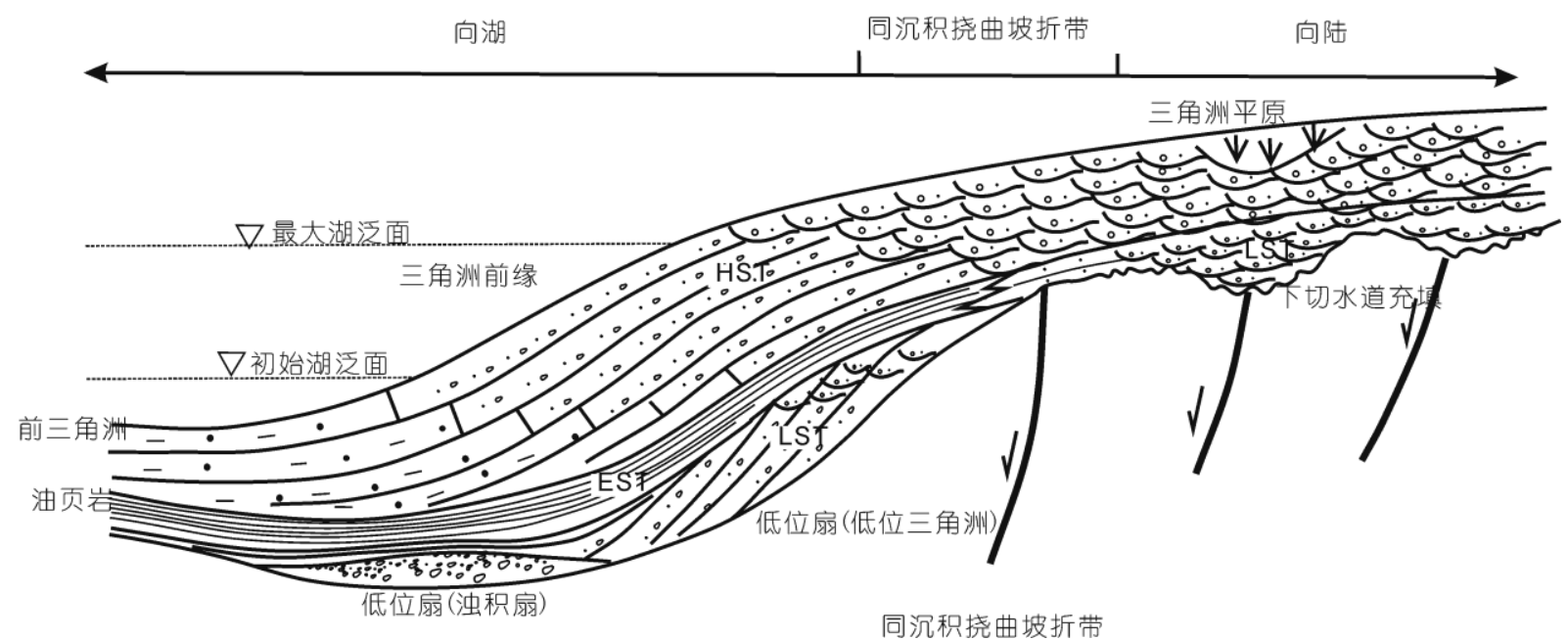

图 13 半地堑凹陷同沉积挠曲坡折(背景)层序体系域构成模式

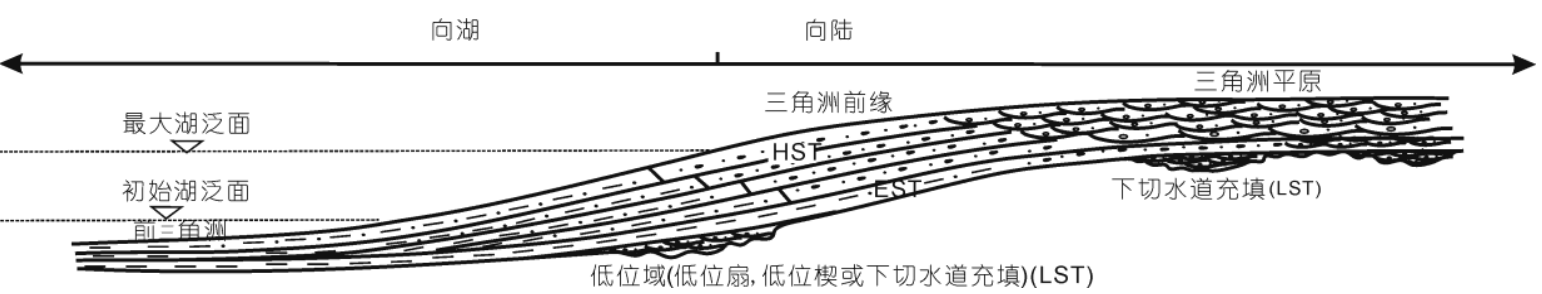

图 14 缓坡(背景)层序体系域构成模式

了 $\mathrm{SSq}_{3-2}$ 层序夏 502 低位楔含油砂体 ${ }^{[6]}$. 在辽河西部 凹陷双南断裂坡折带发现了 $\mathrm{SSq}_{3-4}$ 层序锦 310 低位扇 三角洲含油砂体 ${ }^{[21]}$.

东营凹陷北陡坡断阶状构造坡折带西端发现的 $\mathrm{SSq}_{3-1}$ 层序坨 71, 719 低位楔含油砂体, 在高分辨率地
震剖面上呈显楔形反射, 分布在代表湖扩展体系域 深湖相泥岩的强震幅低速连续反射同相轴之下及坡 折断层的下降盘. 经钻井证实, 该楔形反射发育在深 湖相泥岩和油页岩之下、坡折断层的下降盘. 其岩性 为含角砾的细砾岩、细砾岩、含砾砂岩和砂岩构成的 

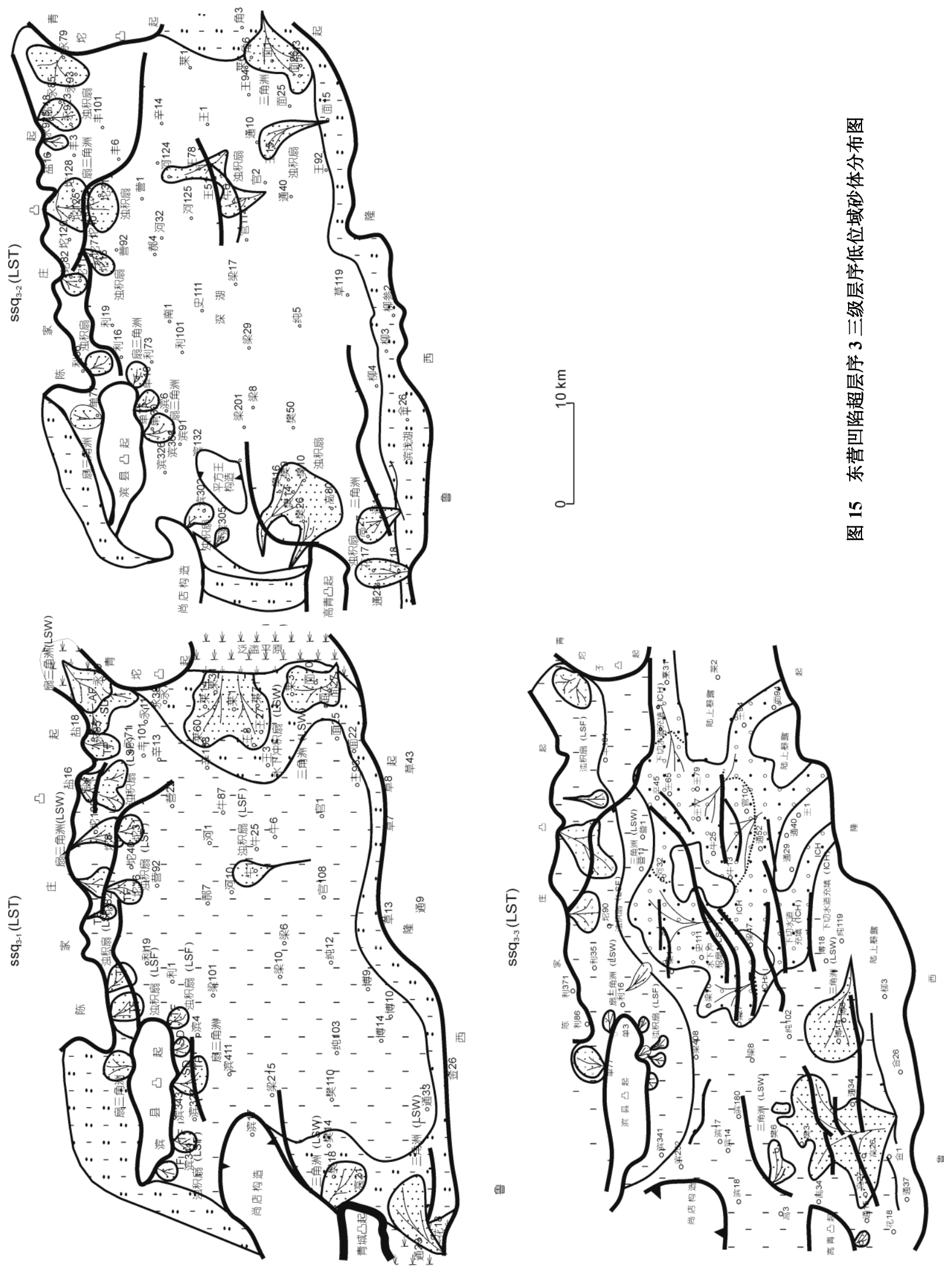
反旋回. 为扇三角洲前缘的碎屑流和水下分流河道 沉积. 其孔隙度为 $8.0 \%$ 10\%, 渗透率约为 $32 \times 10^{-2}$ $\mu \mathrm{m}^{2}$ 储集性能优越. 其顶部覆盖 $\mathrm{SSq}_{3-1}$ 湖扩展体系域 高效烃源岩. 底部通过层序界面与 $\mathrm{SSq}_{2-2}$ 层序优质烃 源岩接触, 故成藏条件良好. 油气藏的空间成因组合 表现为构造坡折带下部为扇三角洲-浊积扇岩性油气 藏, 高位体系域见三角洲滑塌浊积体油藏. 油气主要 来自其顶部 $\mathrm{SSq}_{3-1}$ 层序高效烃源岩和其下部 $\mathrm{SSq}_{2-2}$ 烃 源岩. 油气运聚的输导体系和封堵因素主要为构造 坡折断层和层序界面. 由于该砂体处于盆地地层流 体高压囊的北部边缘, 这些构造坡折断层为地层内 高压含烃流体幕式排烃的主要部位, 在这些部位通 过流体包裹体分析发现较高古地温梯度异常就是证 据. 地层流体高压囊存在的流体压裂、幕式排烃机理 及这些断层可能发生的“单向阀”排油机理都非常有 利于北陡坡低位域砂岩成藏 ${ }^{[6]}$ (图 16).

\section{4 问题讨论}

断陷盆地层序地层的发育主要受盆地构造运动、 沉积物供给及气候条件的共同控制. 不同级别的层 序及层序的体系域构成特征都是上述三种因素共同 作用的结果. 在这三种控制因素中, 盆地构造运动起 主导作用.

不同级别的层序界面与不同级别和规模的不整 合相对应 ${ }^{[22]}$. 一级层序界面是盆地规模的区域不整 合, 界面上下盆地构造环境不同. 渤海湾盆地古近系
同裂谷期超层序组顶(24.6 Ma)、底(65 Ma)界面就是 与区域构造相关的盆地范围的不整合. 其底界面也 就是古近系与中生界之间的不整合与晚白严世末期 渤海湾盆地整体抬升、剥蚀形成的区域性不整合有关. 顶界面也就是古近系与新近系之间的不整合 (24.6 $\mathrm{Ma})$, 可能与印度板块与欧亚板块强烈碰撞产生的远 程效应 ${ }^{[23]}$ 及盆地在渐新世末整体抬升剥蚀形成的区 域不整合面有关. 随后产生的地幔热回沉使得渤海 湾盆地由古近系的同裂谷断陷盆地转化为拗陷盆地 (图 2).

古近系同裂谷期超层序组内, 发育着由盆地幕 式构造演化和区域构造事件共同作用所形成的三个 二级层序界面也可能是构造应力场的转化面. 其中 $\mathrm{SSB}_{2}$ 界面(沙四段与沙三段之间的不整合面, $42.5 \mathrm{Ma}$, T6 反射界面), 是渤海湾盆地构造发展和沉积充填极 为关键的界面. 该界面之下从白严系到沙四段其控 盆断裂展部方向和地层厚度中心的分布方向为 $\mathrm{NW}$ 向 (图 4), 而该界面之上活动断裂的展部方向为 NE-NNE 向. 因此, 该界面是渤海湾盆地构造应力场 的转化面. 该不整合面的发育可能与太平洋板块在 43.5 41.5 Ma 最终完成其运动方向由中生代 NNW 向 NWW 的转变 ${ }^{[24,25]}$ 以及印度板块与欧亚板块在 $45 \sim 42$ $\mathrm{Ma}$ 发生了硬碰撞 ${ }^{[26]}$, 渤海湾盆地构造应力场最终转 化为右旋张扭构造应力场有关. 由于 $42.5 \mathrm{Ma}$ 这个关 键性界面的存在, 使得超层序 1 、超层序 2 与超层序 3, 4 发育的构造背景存在较大差异, 层序体系域构成 特征明显不同.

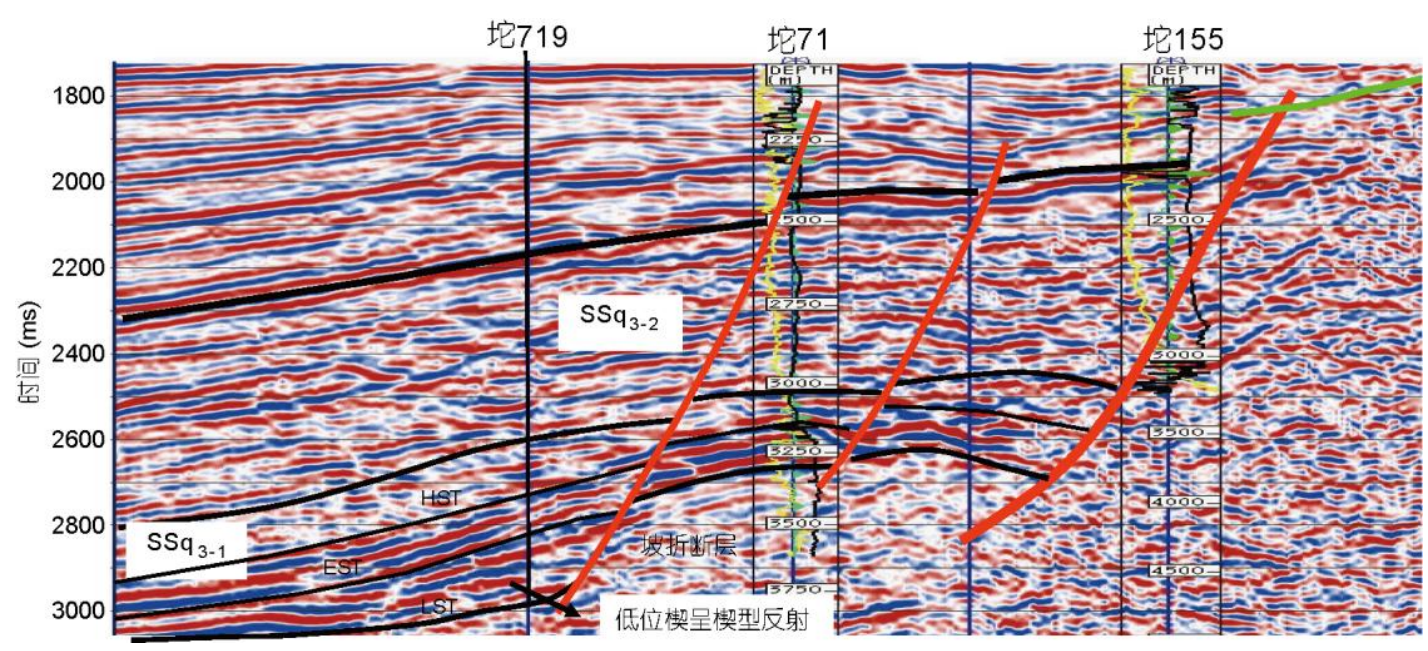

图 16 东营凹陷北陡坡断阶状构造坡折带低位域砂体岩性油气藏地震反射特征 
超层序 1(孔店组)和超层序 2(沙四段)对应裂陷 一幕和裂陷二幕. 据地层和古生物资料分析, 此时盆 地继承了中生界以来左旋张扭应力场特征及构造格 局, 盆地基底沉降速率较小. NWW, NE 向边界断裂 开始拉张, 使盆地总体形成多个咸水湖泊、盐湖或咸 水、微咸水湖泊. 形成了受断裂坡折控制的以发育河 流、冲积扇及干旱湖泊沉积体系为主的层序(图 17, $\mathrm{SSq}_{1}$ )及冲积扇、河流、扇三角洲、半深湖-深湖及滨 浅湖为主的层序(图 17, $\mathrm{SSq}_{2}$ ).

超层序 3(沙三段-沙二段)对应裂陷三幕. 由于 $42.5 \mathrm{Ma}$ 以来使得渤海湾盆地形成强烈的右旋张扭或 以 SN 向伸展为主的构造应力场 ${ }^{[27]}$, 盆地基底沉降速 率和伸展速率达到最大, 气候湿润, NE, NEE 及近 $\mathrm{EW}$ 向伸展构造及各类同沉积断裂坡折、挠曲坡折及 盆缘沟谷发育, 是断裂坡折和挠曲坡折(背景)层序最 为发育的时期. 其最基本特征表现为同沉积构造坡 折带控制层序及体系域的发育 ${ }^{[28]}$. 发育断裂坡折(背 景)层序形式及挠区坡折(背景)层序形式(图 14, $\mathrm{SSq}_{3}$ ). 三级层序低位域分布局限, 湖扩展域以发育深湖相 泥岩和油页岩为特征, 高位域河流三角洲或扇三角 洲发育且厚度巨大, 可识别出四级层序. 如东营凹陷 超层序 3 内发育的各三级层序其高位域分别发育了 3 6 个四级层序(图 6), 南堡凹陷 $\mathrm{SSq}_{3-1}$ 层序高位域发 育 6 个四级层序, 大民屯凹陷 $\mathrm{SSq}_{3-1}$ 层序高位域也发 育 6 个四级层序 ${ }^{[29]}$. 这可能是因为该构造幕强烈的右 旋张扭伸展构造背景及控盆断裂的幕式伸展, 在湖 盆水体有限的条件下导致断裂伸展活动期可容纳空 间快速增长造成湖平面快速下降, 形成层序界面及 低位域. 当构造活动减弱湖泊迅速扩展发育湖扩展 体系域. 当可容纳空间增展速率趋于停止, 湖盆沉积 速率远大于构造沉降速率, 在造成湖平面缓慢下降 形成高位域 ${ }^{[30]}$ 时, 可发育四级层序 ${ }^{[31]}$.

超层序 4(沙一-东营组)对应盆地裂陷四幕盆地 基底沉降和构造伸展速率明显减弱, 除渤海湾盆地 滩海及海域伸展作用较强裂可发育与超层序 3 相同 的同沉积构造坡折层序外, 陆上大部分地区构造活 动减弱, 断裂坡折转化为挠曲坡折或斜坡, 主要发育 挠曲坡折(背景)层序和缓坡(背景)层序(图 17, $\mathrm{SSq}_{4}$ ). 三级层序低位域分布局限, 湖扩展域以发育浅湖为 特征，高位域以河流及三角州为特征.

\section{5 结论}

通过上述分析本文得出以下结论:

(1) 渤海湾盆地东部古近系同裂谷期发育了三 个级别的不整合面。一级不整合界面是发育在同裂 谷期顶、底之间的在全盆地普遍存在的规模较大的区 域性角度不整合界面。二级不整合界面是发育在四 个裂陷幕之间在全盆地存在的区域性角度不整合面. 其中裂陷二幕与裂陷三幕之间的不整合面(沙四段 $\left(\mathrm{E}_{2} s_{4}\right)$ 与沙三段 $\left(\mathrm{E}_{2} s_{3}\right)$ 之间的不整合面, $\left.42.5 \mathrm{Ma}\right)$ 是构 造应力场的转化面. 三级不整合面是在二级不整合 界面限制的地层内发育的局部不整合和沉积间断面, 一般也是三级层序的界面, 在各凹陷发育数量不同.

(2) 渤海湾盆地东部古近系同裂谷期为一个超 层序组(一级层序), 四幕裂陷对应于四个超层序 (二 级层序)。根据三级不整合(层序界面)界面发育特征 在每个超层序可划分出不同的三级层序. 古近系同 裂谷期可划分出 10 12 个三级层序.

（3）超层序 1 、超层序 2 形成于裂陷 1 和 2 幕盆 地基底沉降速率较小和干旱气候条件下，层序的发 育受 NW 及 NE 向同沉积断裂坡折带的控制, 主要发 育以河流、冲积扇及干旱湖泊沉积体系为主的层序及 以冲积扇、河流、扇三角洲、半深湖及滨浅湖为主的 层序. 超层序 3 形成于裂陷 3 幕盆地基底沉降速率和 伸展速率达到最大, 断陷、伸展作用强烈的构造背景 和湿润的气候条件下，层序的发育主要受同沉积断 裂坡折(背景)和挠曲坡折(背景)控制，形成以湖泊、河 流(扇)三角洲为主的同沉积断裂坡折(背景)和挠曲坡 折(背景)层序. 超层序 4 形成于裂陷 4 幕盆地基底沉 降速率和伸展速率减小, 断陷、伸展作用减弱的构造 背景下，除渤海湾盆地滩海及海域伸展作用较强烈 可发育与超层序 3 相同的同沉积构造坡折层序外，陆 上层序的发育主要受挠曲坡折(背景)和缓坡(背景)控 制，形成以浅湖、三角洲和河流体系为主的层序.

(4) 超层序 2 和 3 内发育的三级层序低位域砂体 的发育主要受同沉积断裂坡折带的控制，并沿同沉 积断裂坡折带分布. 凹陷内同沉积断裂坡折带从早 期层序到晚期层序由凹陷边缘向中心迁移，因此同 沉积断裂坡折带及受其控制的低位域砂体的发育带 也由凹陷边缘向中心迁移。层序低位域砂体发育带 分布在湖扩展域泥岩之下, 成藏条件良好, 是岩性油 气藏勘探的有利区带. 


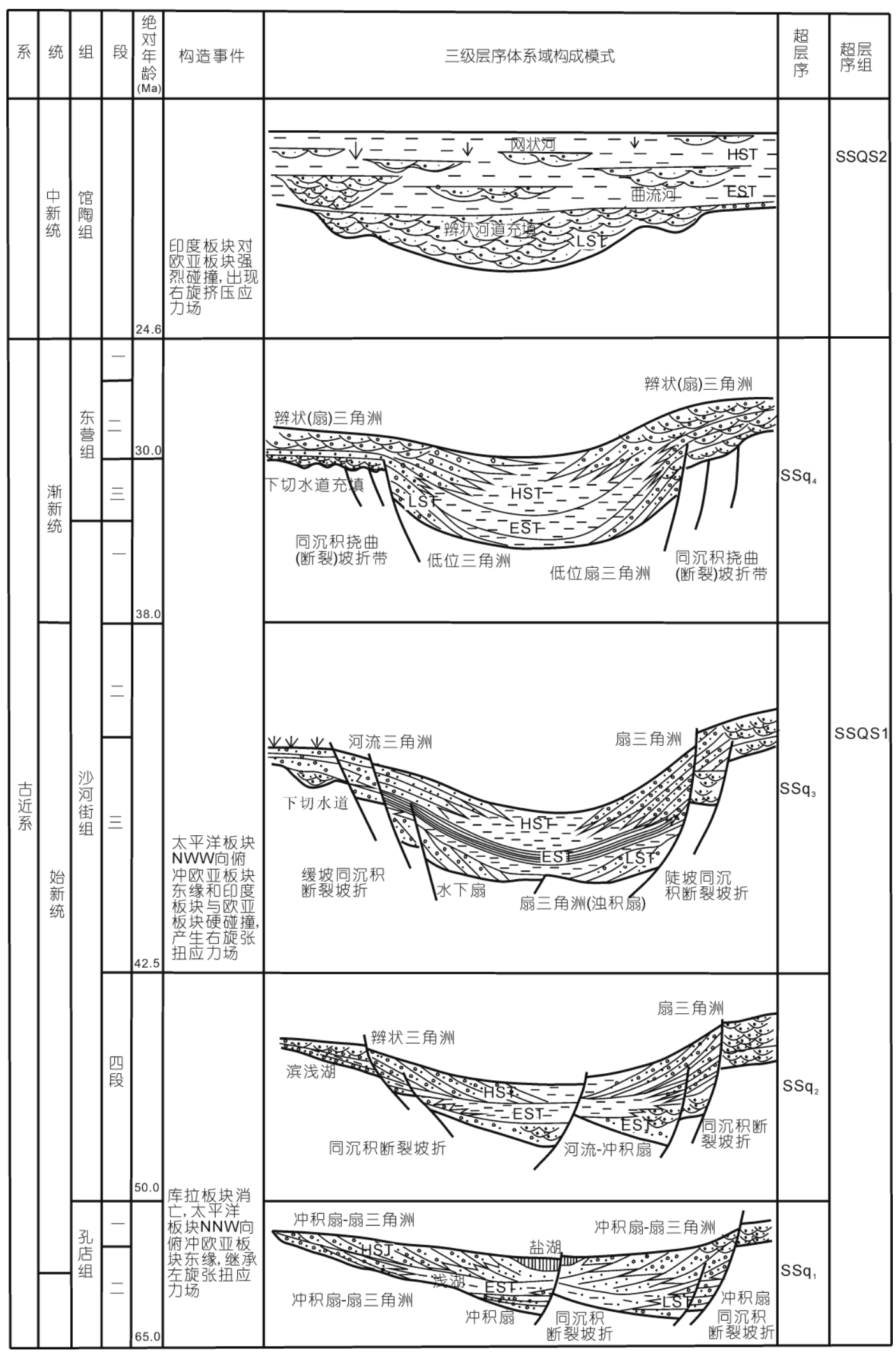

图 17 渤海湾盆地层不同构造幕(超层序)层序体系域发育特征 


\section{参考文献}

1 纪友亮, 张世奇. 陆相断陷湖盆层序地层学. 北京: 石油工业出版社, 1996. 84-121

2 池英柳, 张万选, 张厚福. 陆相断陷盆地层序成因初探. 石油学报, 1996, 17: 19-26

3 冯有良. 东营凹陷下第三系层序地层格架及盆地充填模式. 地球科学, 1999, 14: 634-642

4 李思田, 潘元林, 陆泳潮. 断陷湖盆隐蔽油气藏预测及勘探的关键技术一一高精度地震探测基础上的层序地层学研究. 地球科学, 2003, 27: 502-598

5 林畅松, 潘元林, 肖建新, 等. 构造坡折带——断陷湖盆层序和油气预测的重要概念. 地球科学, 2000, 25: 260-267

6 冯有良, 邱以刚. 高精度层序地层学在济阳坳陷下第三系隐蔽油气藏勘探中的应用. 石油学报, 2003, 24: 49-52

7 孟祥化, 葛铭. 中朝板块层序、事件和演化. 北京: 科学出版社, 2004. 535-539

8 冯有良. 阳信凹陷构造岩浆演化与油气聚集. 石油天然气地质, 1994, 15: 173-179

9 徐道一, 姚益民, 张海峰, 等. 山东东营凹陷渐新统东营组的天文地层研究. 地层学杂志, 2007, 31(增刊 II): 471-481

10 漆家福, 杨桥, 陈发景, 等. 辽东湾-下辽河盆地新生代构造的运动学特征及其演化过程. 现代地质, 1994, 8: 34-42

11 冯有良, 李思田, 解习农. 陆相断陷盆地层序地层形成动力学与层序地层模式. 地学前缘, 2000, 7: 119-132

12 Hubbard R J V. Depositional sequence boundaries on Jurassic and early Cretaceous rifted continental margins. AAPG Bull, 1988, 71: $49-72$

13 Williams G D. Tectonics and Seismic sequence stratigraphy: An introduction. In: Williams G D, Dobb A, eds. Tectonics and Seismic Sequence Stratigraphy. London: Geological Society Special Publication, 1993. 1-13

14 Jackson C A L, Gawthorpe R L, Sharp I R, et al. Normal faulting as a control on the stratigraphic development of shallow marine syn-rift sequence: The Nukhul and Lower Rudeis Formations, Hammam Faraun fault block, Suez Rift, Egypt. Sedimentology, 2005, 52: 313-338

15 Howell J A, Flint S S. A model for high resolution sequence stratigraphy within extensional basins. In: Howell J A, Aitken J F, eds. High Resolution Stratigraphy: Innovations and Applications. London: Geology Society Special Publication, 1996. 129—137

16 任建业，陆永潮，张清林．断陷盆地构造坡折带形成机制及其对层序发育的控制作用．地球科学, 2004, 29: 596一603

17 Vail P R, Audemard F, Bowman S A, et al. The stratigraphic signatures of tectonics, eustasy and sedimentology-An overview. In: Einsele G, Ricken W, Seilacher A, eds. Cycles and Events in Stratigraphy. Berlin: Springer-verlag, 1991. 617—659

18 冯有良, 周海民, 李思田. 陆相断陷盆地层序类型与构造特征. 地质论评, 2004, 50: 41一 49

19 Olson T. Sequence stratigraphy, alluvial architecture and potential reservoir heterogeneities of fluvial deposits: Evidence from outcrop studies in Price Canyon, Utah (Upper Cretaceous and Lower Tertiary). In: Van Wagoner J C, Bertram G T, eds. Sequence Stratigraphy of Foreland Basin Deposits—Outcrop and Subsurface Examples From the Cretaceous of North America. AAPG Memoir, 1995, 64: 75-94

20 冯有良, 李思田. 东营凹陷沙河街组三段层序低位域砂体沉积特征. 地质论评, 2001, 47: 278-286

21 冯有良, 鲁卫华. 辽河西部凹陷古近系层序地层与地层岩性油气藏预测. 沉积学报, 2009, 27: 38-44

22 薛良清. 论沉积层序沉积级别的划分. 石油勘探与开发, 1989, 25: 10-14

23 万天丰. 中国大地构造学纲要. 北京: 地质出版社, 2004. 176-179

24 Sharp W D, Clague D A. 50-Ma initiation of Hawaiian-Emperor Bend records major change in Pacific plate motion. Science, 2006, 3131 : $10-13$

25 Gordon R G, Jurdy D M. Cenozoic global plate motions. J Geophys Res, 1986, 91: 12389-12406

26 Lee T Y, Lawver L A. Cenozoic plate reconstruction of Southeast Asia. Tectonophysics, 1995, 251: 85—138

27 周建勋, 周建生. 渤海湾盆地新生带构造变形机制: 物理模拟和讨论. 中国科学 D 辑: 地球科学, 2006, 36: 507-519

28 林畅松, 任建业, 郑和荣. 渤海湾盆地东营、沾化凹陷早第三系同沉积断裂作用对沉积充填的控制. 中国科学 D辑: 地球科学, 2003, 33: $1025-1036$

29 冯有良. 大民屯凹陷沙四-沙三段层序地层格架及岩性油气藏预测. 岩性油气藏, 2008, 20: 14-19

30 Strecker U, Stridtmann J R, Smithson S B. A conceptual tectonostratigraphic model for seismic facies migration in a fluvio-facustrine extensional basin. AAPG Bull, 1999, 83: 43-61

31 Van Wagoner J C, Mitchun R M, Campion K M, et al. Siliciclastic sequence stratigraphy in well, core and outcrops and outcrops-concept for high-resolution correlation of times and facies. AAPG Methods Explor Ser, 1990, 7: 1—55 